\title{
Exogenous 1-Aminocyclopropane-1-carboxylic acid Controls Photosynthetic Activity, Accumulation of Reactive Oxygen or Nitrogen Species and Macroelement Content in Tomato in Long-term Experiments
}

\author{
Péter Borbély ${ }^{1,2} \cdot$ Szilvia Bajkán ${ }^{3} \cdot$ Péter Poór $^{1} \cdot$ Irma Tari $^{1}$
}

Received: 13 July 2018 / Accepted: 21 December 2018 / Published online: 20 February 2019

(c) The Author(s) 2019

\begin{abstract}
Exogenous ethylene (ET) or its precursor, 1-aminocyclopropane-1-carboxylic acid (ACC) may increase stress tolerance of plants in long-term experiments. ACC applied in hydroponic culture of tomato (Solanum lycopersicum L. cv. Rio Fuego) brought about concentration-dependent differences in plant responses. ACC at $0.01 \mu \mathrm{M}$ changed $\mathrm{K}^{+}$distribution between shoots and roots but at higher concentrations $\mathrm{K}^{+} /{ }^{86} \mathrm{Rb}^{+}$uptake was inhibited. Surprisingly, excess $\mathrm{Na}^{+}$and reduced $\mathrm{K}^{+}$accumulation could be measured in root and leaf tissues, respectively, which at $100 \mu \mathrm{M}$ ACC led to a decreased $\mathrm{K}^{+} / \mathrm{Na}^{+}$ratio and to a weak ionic stress in these plant organs. $\mathrm{ACC}$ at low concentrations increased the net $\mathrm{CO}_{2}$ fixation rate $\left(\mathrm{A}_{\mathrm{N}}\right)$, however, at $100 \mu \mathrm{M}$, it triggered a parallel decline in stomatal conductance, $A_{N}$ and in the actual quantum yield of photosystem II. Photosystem I (PSI) was less sensitive to ACC, lower concentrations caused an increasing tendency in the effective quantum yield and changed the non-photochemical quenching profile of PSI from donor-side dominant to acceptor-side-dominant limitation. Photoinhibition was avoided via the dissipation of light energy by regulated non-photochemical quenching and by transiently enhanced cyclic electron flow (CEF) around PSI. The decrease in CEF at $100 \mu \mathrm{M}$ ACC correlated well with the accumulation of $\mathrm{O}_{2}{ }^{--}$and $\mathrm{H}_{2} \mathrm{O}_{2}$ in the leaf tissues suggesting that molecular oxygen may function as an electron acceptor when natural acceptors of the linear electron transport were over-reduced. Concentration-dependent changes in soluble sugars and sorbitol as osmoprotectants may also contribute to the stress resistance of plants elicited by ET/ACC.
\end{abstract}

Keywords 1-Aminocyclopropane-1-carboxylic acid $\cdot$ Ethylene $\cdot$ Reactive oxygen and nitrogen species $\cdot$ Photosystem I $\cdot \mathrm{K}^{+} /$ $\mathrm{Na}^{+}$ratio $\cdot$ Soluble sugars

Irma Tari

tari@bio.u-szeged.hu

1 Department of Plant Biology, Faculty of Science and Informatics, University of Szeged, Közép fasor 52, Szeged 6726, Hungary

2 Biological Doctoral School, Faculty of Science and Informatics, University of Szeged, Közép fasor 52, Szeged 6726, Hungary

3 School of Geography and the Environment, Oxford University Centre for the Environment, University of Oxford, South Parks Road, Oxford OX1 3QY, UK

\section{Introduction}

The gaseous plant hormone, ethylene (ET), plays an important role in growth, development, and responses of plants to biotic and abiotic stresses (Abeles et al. 1992). ET can be synthesized in essentially all plant organs (Santner et al. 2009). The immediate precursor of ET, 1-aminocyclopropane-1-carboxylic acid (ACC) is a cyclic $\alpha$-amino acid, which is generated by various isoforms of ACC synthases (ACS) and oxidised to ET by ACC oxidases. Although ACS catalyses the rate-limiting step in the ET biosynthetic pathway, the available free ACC pool in the tissues may be regulated by the formation of ACC conjugates (malonyl-, $\gamma$-glutamyl-, and jasmonoyl-ACC), which can affect the ACC-induced ET production. While ET can diffuse from cell to cell, long distance ET responses can also be 
accomplished through the transport of ACC from the roots to the shoot or vice versa during stress and developmental processes (Van de Poel and Van Der Straeten 2014).

Within any particular plant, an increased level of ET and ACC is typically formed in response to abiotic stress factors (Yang and Hoffmann 1984) or to pathogenic and nonpathogenic microorganisms (Broekgaarden et al. 2015). Generation of "stress ethylene" often occurs in two peaks. It was observed that the treatment of leaf discs of wild-type (WT) tobacco (Nicotiana tabacum L.) with $\mathrm{H}_{2} \mathrm{O}_{2}$ induced an oxidative stress and a time-dependent expression of various $N t A C S$ genes. The NtACS4 was expressed during the first, while NtACSI during the second maximum of ET production. The second, larger peak in stressed plant tissues lasted $30 \mathrm{~h}$ in this system (Wi et al. 2010) but it may extend for weeks (Rodríguez-Serrano et al. 2006), thus ET may initiate detrimental processes such as senescence, chlorosis and leaf abscission.

ET and ACC can accumulate exogenously in plant surroundings. Motor vehicle exhaust includes measurable amounts of ET and thus it is an unusual air pollutant that controls plant development. In unpolluted areas, the ET concentration ranged between 0.03 and $0.50 \mu \mathrm{L} \mathrm{L}^{-1}$, however, in polluted regions ET concentration could be as high as $0.70 \mu \mathrm{L} \mathrm{L}^{-1}$ (Abeles and Heggestad 1973). Although ET at relatively low concentrations (below $0.1 \mu \mathrm{L} \mathrm{L}^{-1}$ ) can promote leaf (Dubois et al. 2018), coleoptile, hypocotyl or petiole elongation in certain species, higher concentrations are inhibitory (Pierik et al. 2006). In most cases, ET reaches the growth inhibiting level at $1 \mu \mathrm{L} \mathrm{L}^{-1}\left(6.5 \times 10^{-9} \mathrm{M}\right.$ at $\left.25^{\circ} \mathrm{C}\right)$, plants exposed to these concentrations exhibited typical symptoms of excess ET: reduced growth, leaf epinasty and eventually premature senescence (Abeles et al. 1992). Fortunately, due to stringent vehicle exhaust regulations, the ET concentration in the air was substantially reduced to such an extent that it can only reach physiologically active values at special circumstances such as biomass burning or local/ anthropogenic emissions (Toon et al. 2018).

The partial pressure of ET in the soil gas phase is much higher, thus ET concentrations can reach approximately $0.50-17.76 \mu \mathrm{L} \mathrm{L}^{-1}$ in the soil air (Abeles et al. 1992). Soil ET can be produced chemically by decomposition of organic substances and some soil-grown microorganisms are also able to synthesize ET from different precursors (Nascimento et al. 2018). The amount of ACC in soil water can reach as high as $0.23-0.52 \mu \mathrm{mol} \mathrm{L}{ }^{-1}$ in the surroundings of flooded tomato roots (Else et al. 1995). Along with other small molecules, a part of the ACC synthesized by plant tissues is exuded from the roots into the soil and may be taken up not only by other plants but by the bacteria living in loose association with host plants in the rhizosphere.

These soil bacteria often promote plant growth because they synthesize an enzyme, ACC deaminase (ACCD), which subsequently degrades ACC, thus ACCD stimulates root growth by lowering ET levels in soil air (Honma and Shimomura 1978). Some rhizobacteria can produce the plant hormone, indole-3-acetic acid, which stimulates the synthesis of ET in root tissues. These growth-promoting bacteria also facilitates the uptake of certain essential elements and prevent the deleterious effect of several environmental stressors by inducing systemic tolerance in plants (Zaidi et al. 2016; Nascimento et al. 2018). This suggests that the maintenance of an appropriate ET/ACC concentration in the soil is an important factor for the healthy development of plants.

Stress ET was found to play a prominent role in the control of uptake and accumulation of mineral nutrients in plants under abiotic stress conditions (Iqbal et al. 2013). Staal et al. (2011) demonstrated that exogenous ACC induced an apoplastic alkalinisation in the cells of the fast elongating zone in Arabidopsis root. The alkalinisation can be reversed by fusicoccin, an inducer of plasma membrane (PM) $\mathrm{H}^{+}$-ATPase suggesting that ACC by itself may interfere with ion transport.

Increased ET production and up-regulation of genes involved in ET biosynthesis were found in Arabidopsis plants under low potassium conditions (Jung et al. 2009). ET signalling stimulated the production of reactive oxygen species (ROS), which is essential for changes in root hair development and in the inhibition of lateral root growth, important tolerance mechanisms to potassium deficiency (Schachtman 2015). Jung et al. (2009) also revealed that ET, acting upstream of ROS, could partially restore potassium homeostasis by the upregulation of an important carrier of $\mathrm{K}^{+}$, HIGH-AFFINITY $\mathrm{K}^{+}$TRANSPORTER5 (HAK5), localized to root PM.

Beside potassium deficiency, ET also promoted salt tolerance under high salinity by regulating $\mathrm{Na}^{+} / \mathrm{K}^{+}$homeostasis via ROS-dependent and ROS-independent mechanisms (Zhang et al. 2016). ROS may regulate $\mathrm{Na}^{+}$transport and thus $\mathrm{K}^{+} / \mathrm{Na}^{+}$ratio by increasing the stability of SALT OVERLY SENSITIVE1 (SOS1) $\mathrm{Na}^{+} / \mathrm{H}^{+}$antiporter in PM, which transports $\mathrm{Na}^{+}$to the apoplast (Chung et al. 2008) or by increasing the expression and activity of PM ATPase (Zhang et al. 2007). Besides ROS, plant tissues produce reactive nitrogen forms (RNF) (for example, nitric oxide, $\mathrm{NO}$ and peroxynitrite, $\mathrm{ONOO}^{-}$) during abiotic stress. Thus, ET can cooperate not only with ROS but also with RNF during stress acclimation. $\mathrm{H}_{2} \mathrm{O}_{2}$ and $\mathrm{NO}$ acted interdependently in salt stress responses and contributed to the maintenance of $\mathrm{K}^{+} / \mathrm{Na}^{+}$homeostasis and antioxidant defence in poplar cell cultures exposed to high salinity (Sun et al. 2010).

Moreover, the generation of ROS by ET could be observed during normal development or upon exogenous treatments with ET-releasing compounds. Emergence of adventitious root primordia was preceded by ET-induced-, 
$\mathrm{H}_{2} \mathrm{O}_{2}$-mediated local death of epidermal cells at stem nodes of rice. Exogenous $\mathrm{H}_{2} \mathrm{O}_{2}$ or enhancement of endogenous $\mathrm{H}_{2} \mathrm{O}_{2}$ by an ET-releasing compound, ethephon promoted epidermal cell death in a dose-dependent manner (Steffens and Sauter 2009). In contrast to a number of abiotic stresses, exogenous ACC and ethephon treatments could reduce NO levels in Vicia faba guard cells, which contributed to stomatal reopening after abscisic acid-induced closure (She and Song 2012).

Plant ET production depends on the illumination of tissues (Bassi and Spencer 1983) and on light intensity. Average $\left(600 \mu \mathrm{mol} \mathrm{m} \mathrm{m}^{-2} \mathrm{~s}^{-1}\right)$ photosynthetically active radiation increased ET emanation from leaves of tomato while higher values (900-1200 $\mu \mathrm{mol} \mathrm{m}^{-2} \mathrm{~s}^{-1}$ ) were inhibitory (Basiouny et al. 1994). Photosynthetic activity was inhibited by ET in most plant species, while it was not affected in others (Taylor and Gunderson 1986; Ceusters and Van de Poel 2018); however, exogenous ET was found to stimulate photosynthesis only in mustard plants (Khan 2004).

It has been reported that ET (Pallas and Kays 1982; Ceusters and Van de Poel 2018), ACC or ethephon (Desikan et al. 2006) induced stomatal closure in a number of species. The ET-induced inhibition of the net $\mathrm{CO}_{2}$ assimilation rate depended first of all on the effect of ET on stomatal conductance, which limited $\mathrm{CO}_{2}$ diffusion to leaf mesophyll. However, it has to be mentioned that in most of these studies the concentration of exogenously applied ET exceeded the highest concentrations detected in the polluted air. The control of photosynthesis by ET proved to be direct in juvenile tissues, while the hormone acted indirectly in mature leaves by promoting senescence (Ceusters and Van de Poel 2018). It was found by Grbic and Bleecker (1995) that juvenile, non-senescing leaves of Arabidopsis ET-insensitive ethylene-resistant 1-1 (etrl-1) mutants exhibited lower ribulose1,5-bisphosphate carboxylase-oxygenase (Rubisco) activity, lower expression of photosynthetically active genes encoding chlorophyll $a / b$-binding proteins and the Rubisco small subunit and contained less chlorophyll suggesting the role of ET in these processes. There were, however, contradicting reports concerning the effect of ET on photosystem II (PSII) and photosystem I (PSI) quantum efficiency and light dissipation processes in WT plants or ET-resistant mutants (Ceusters and Van de Poel 2018). In another study, ET in an ET overproducer eto1-1 Arabidopsis mutant could control non-photochemical quenching (NPQ) by reducing the activity of violaxanthin deepoxidase, the enzyme participating in xanthophyll cycle (Chen and Gallie 2015). Moreover, ET could also affect the partitioning of $\mathrm{CO}_{2}$ assimilates and metabolism of sugars in plant organs (Iqbal et al. 2011).

ACC is widely used as an exogenous ET-generator molecule in various experiments, and it was found that this effect depends on dose, on the type of application and on physiological conditions of plants such as the age, organ type or presence of other stress factors (Trujillo-Moya and Gisbert 2012). It has recently been revealed that ACC uptake is mediated by a lysine histidine transporter (LHT1) amino acid transporter protein in Arabidopsis. Mutation in LHT1 designated as ACC-resistant2 (are-2), resulted in a dosedependent resistance to exogenously applied ACC (Shin et al. 2015).

Because ET can be derived from various sources and ACC exuded by plant roots can reach the physiologically active concentration in the plant environment and these compounds are able to promote or inhibit plant growth, one has to take into account the long-term effects of ET/ ACC on most important physiological functions of plants both in the natural environment or in the greenhouse. However, our knowledge is far from complete about the ACC or ACC-induced ET impact in long-term experiments. What is the level of ET production in root and leaf tissues of plants exposed to ACC for 1 week? How does ACC-derived ET affect the ion accumulation and the generation of various reactive oxygen $\left(\mathrm{H}_{2} \mathrm{O}_{2}\right.$, superoxide anion radical, $\left.{ }^{\bullet} \mathrm{O}_{2}{ }^{-}\right)$, and nitrogen $\left(\mathrm{NO}, \mathrm{ONOO}^{-}\right)$forms? The effect of ET on the activity of PSII has already been described by other authors (Iqbal et al. 2011) but there is little information about its effect on PSI activity and about the accumulation and distribution of various sugars between the shoot and the root. Thus, in this study, we investigated the effect of different ACC concentrations on macroelement content, photosynthetic processes and on the abundance of reactive oxygen and nitrogen species, as possible components of exogenous ET/ACC-induced eustress, which may enhance plant tolerance to other abiotic stresses in tomato (S. lycopersicum cv. Rio Fuego) plants after 1 week of ACC application.

\section{Materials and Methods}

\section{Plant Material and Determination of Growth Parameters}

Tomato plants (S. lycopersicum L. cv. Rio Fuego) were grown hydroponically in a controlled environment (12/12 h light/dark period, $300 \mu \mathrm{mol} \mathrm{m} \mathrm{m}^{-2} \mathrm{~s}^{-1}$ photon flux density (PPFD), $25 / 22{ }^{\circ} \mathrm{C}$ day/night temperature, $55-56 \%$ relative humidity). The seedlings were grown in perlite for 2 weeks, then two plants were transferred into $0.8 \mathrm{~L}$ pots containing a modified Hoagland solution as described earlier (Poór et al. 2011). After plants reached the morphological age of the seven leaf-level (6-7-week-old plants), $0.01 \mu \mathrm{M}, 1.0 \mu \mathrm{M}$ or $100 \mu \mathrm{M}$ ACC (Sigma-Aldrich, St. Louis, MO) was added to the culture media. The ET in the air of the greenhouse was trapped with a saturated solution of potassium permanganate $\left(\mathrm{KMnO}_{4}\right)$ and mercury perchlorate $\left(\mathrm{HgClO}_{4}\right)$ put in separated vessels. The treatments, with the exception of ion 
uptake experiments, lasted for 7 days. The nutrient solution was changed (with or without freshly dissolved ACC) every 2 days. All of the growth parameters, the shoot and root length, fresh and dry weight (DW) of plant organs were determined on the day 7 after ACC treatments. One individual plant was used for the preparation of one sample, and the number of samples is added in figure legends $(n)$, for example, $n=4$ in the case of ET production refers to data obtained separately from the same leaf or root tissues of four different plants put in separate vials at every treatment and every time point. Shoots and roots were desiccated at $60{ }^{\circ} \mathrm{C}$ until equilibrium before DW determination. Samples for other measurements were prepared at the same incubation time from root tips or fully expanded young leaves (in third or fourth leaf-level) from 8:00 am to 13:00 pm. Photosynthetic parameters were determined on the apical leaflets of third mature leaves (counted from shoot tip) and the same leaf was monitored for 1 week during photosynthesis measurements. Three individual plants were used for gas exchange measurements and four plants for the determination of fluorescence induction parameters at all sampling times. All experiments were repeated three times.

\section{Measurement of ET Evolution}

The ET production of roots and leaves was determined by a Hewlett-Packard 5890 series II gas-chromatograph (Hewlett-Packard, Wilmington, USA, DE) equipped with a flame ionization detector and a column with activated alumina as described by Poór et al. (2014). One gram of washed leaf or root tissues was put and closed immediately into $22 \mathrm{~mL}$ gastight flasks fitted with silicone-rubber stopper on the first, second and seventh days of ACC treatments. Samples were prepared in four replicates. For maintaining the tissue hydration during incubation $1 \mathrm{~mL}$ of deionized-water was added to the samples. The amount of ET produced during the 1-h incubation period was determined by removing $2.5 \mathrm{~mL}$ from the gas space of flasks with a gas-tight syringe, which was injected onto the column. The gas pressure in the flasks was maintained by injecting $2.5 \mathrm{~mL}$ of distilled water into incubation flasks in parallel with sample withdrawal. The volume of the air space above plant material was determined individually in flasks by filling them with water to overflowing after the incubation period. A set of ET standards was used to calculate the quantity of ET generated by the samples. The results are given in $\mathrm{nL} \cdot(\text { fresh weight, } \mathrm{g})^{-1} \mathrm{~h}^{-1}$.

\section{Determination of $\mathrm{K}^{+}$Uptake}

${ }^{86} \mathrm{Rb}^{+}$(Perkin-Elmer/NEN, Woodbridge, Canada) isotope labelling was used as a tracer for monitoring $\mathrm{K}^{+}$uptake (Szepesi et al. 2009). The uptake solution contained deionized water, $1 \mathrm{mM} \mathrm{KCl}, 0.5 \mathrm{mM} \mathrm{CaCl}_{2}$, and $185 \mathrm{kBq} \mathrm{L}^{-1}$ of ${ }^{86} \mathrm{RbCl}$. The experiments were performed, for technical reasons, with 3-week-old plants. The roots of intact plants were washed for $1 \mathrm{~min}$ in deionized water prior to the experiments. For the detection of the direct effect of ACC on $\mathrm{K}^{+} /{ }^{86} \mathrm{Rb}^{+}$uptake, the plants were placed into the uptake solutions containing $0.1,1.0$ and $100 \mu \mathrm{M}$ concentrations of ACC and incubated for $6 \mathrm{~h}$ at $25^{\circ} \mathrm{C}$. Prior to aftereffect determination, the plants were pre-treated with the same ACC solutions for $24 \mathrm{~h}$, then the roots were washed and transferred into the uptake solution for $6 \mathrm{~h}$, at $25^{\circ} \mathrm{C}$. To remove surface-bound isotopes, the roots were washed three times in $150 \mathrm{~mL}$ of distilled water for 1-1 min after $6 \mathrm{~h}$ of incubation. Whole root and shoot samples from four plants were prepared per treatments and dried at $70{ }^{\circ} \mathrm{C}$. The radioactivity of the samples was determined with a liquidscintillation counter (Canberra Packard Prias PL, Tri-Carb). Three measurements were made from each plant sample for $1 \mathrm{~min}$ and $1 \mathrm{~mL}$ of the uptake solution was used as standard.

\section{Determination of Macroelement and Iron Content}

The macroelement content of shoots and roots was determined by atomic absorption spectrometry (Hitachi Z-8200, Tokyo, Japan) (Poór et al. 2014). One hundred milligram of dry samples was digested in $5 \mathrm{~mL}$ of concentrated $\mathrm{HNO}_{3}$ and $4 \mathrm{~mL}$ of $30 \% \mathrm{H}_{2} \mathrm{O}_{2}$ for $3 \mathrm{~h}$ at $200{ }^{\circ} \mathrm{C}$ in a microwave destructor (MarsXpress, CEM, USA). The cooled samples were diluted to $20 \mathrm{~mL}$ with HPLC-grade water, transferred to Packard glass tubes and stored until analysis.

\section{Fluorescence Microscopy Measurements}

Changes in $\mathrm{H}_{2} \mathrm{O}_{2}, \mathrm{O}_{2}{ }^{\bullet-}$, $\mathrm{NO}$ and $\mathrm{ONOO}^{-}$levels in 1-cmlong root tips and content of $\mathrm{NO}$ and $\mathrm{ONOO}^{-}$in the leaves were detected with fluorescent dyes (Poór et al. 2015) and altogether 16 tissue segments were prepared from 4 individual plants. The leaf discs, $10 \mathrm{~mm}$ in diameter, were infiltrated with the dyes under vacuum. $\mathrm{O}_{2}{ }^{\bullet-}$ was visualized by $10 \mu \mathrm{M}$ dihydroethidium (DHE) and $\mathrm{H}_{2} \mathrm{O}_{2}$ by $50 \mu \mathrm{M}$ 10-acetyl-3,7-dihydroxyphenoxazine (AR; ADHP or Amplifu $\left.^{\mathrm{TM}} \mathrm{Red}\right)$. NO was detected with $10 \mu \mathrm{M}$ 4-amino5-methylamino-2',7'-difluorofluorescein diacetate (DAFFM DA) and $\mathrm{ONOO}^{-}$with $10 \mu \mathrm{M}$ aminophenyl fluorescein (APF). All dyes were purchased from Sigma-Aldrich, St. Louis, MO, USA. Stock solutions of dyes were diluted with $25 \mathrm{mM}$ tris(hydroxymethyl) aminomethane (TRIS-HCl, $\mathrm{pH}$ 7.4) buffer prior to use. The samples were dark-incubated in the presence of the specific fluorescent dyes at $24{ }^{\circ} \mathrm{C}$ for 30 min (DHE and AR) or for 40 min (DAF-FM DA and APF), then they were washed twice with $25 \mathrm{mM}$ TRIS-HCl buffer ( $\mathrm{pH}$ 7.4) for $5 \mathrm{~min}$.

Fluorescence intensity was detected with a Zeiss Axiovert 200M type fluorescent microscope (Carl Zeiss Inc., Jena, 
Germany), equipped with a $5 \times$ objective using excitation at $450-495 \mathrm{~nm}$ and emission at $515-565 \mathrm{~nm}$ or excitation at $535-585 \mathrm{~nm}$ and emission at $600-655 \mathrm{~nm}$ for the measurement of DAF-FM, DHE and APF or AR, respectively. Digital photographs were taken with a high-resolution Axiocam HR type, HQ CCD camera (Carl Zeiss Inc., Jena, Germany) equipped with filter sets 10 and 20HE. Pixel intensity was determined with Axiovision Rel 4.8 software (Carl Zeiss Inc., Münich, Germany) (Poór et al. 2015).

\section{Determination of Superoxide Anion and $\mathrm{H}_{2} \mathrm{O}_{2}$ in the Leaf Tissues}

The $\mathrm{H}_{2} \mathrm{O}_{2}$ content was measured according to Takács et al. (2017). One hundred $\mathrm{mg}$ of leaf tissue was homogenized with $0.5 \mathrm{~mL}$ of ice-cold, $0.1 \%$ trichloroacetic acid and the samples were centrifuged at $10,000 \times g$ for $20 \mathrm{~min}$ at $4{ }^{\circ} \mathrm{C}$. The reaction mixture contained $0.25 \mathrm{~mL}$ of $10 \mathrm{mM}$ phosphate buffer ( $\mathrm{pH} 7.0$ ), $0.5 \mathrm{~mL}$ of $1 \mathrm{M}$ potassium iodide (KI) and $0.25 \mathrm{~mL}$ of the supernatant. The absorbance of the samples was measured after $10 \mathrm{~min}$ at $390 \mathrm{~nm}$ by a Uvikon XL (Secomam, Alés Cedex, France) spectrophotometer.

The quantification of $\mathrm{O}_{2}{ }^{\bullet-}$ was performed according to Bournonville and Diaz-Ricci (2010). During histochemical staining, three intact leaves from different plants were vacuum infiltrated with $10 \mathrm{mM}$ sodium azide (Sigma-Aldrich, St. Louis, MO, USA) for $10 \mathrm{~min}$, then with $0.1 \%$ nitrotetrazolium blue chloride (NBT) sodium salt (Sigma-Aldrich, St. Louis, MO, USA) solution for $2 \mathrm{~min}$, and incubated for $2 \mathrm{~h}$ in complete darkness. Both substances were dissolved in $50 \mathrm{mM}$ potassium phosphate buffer ( $\mathrm{pH}$ 7.7). The samples were boiled in $96 \%$ ethanol at $96{ }^{\circ} \mathrm{C}$ for $2 \times 30 \mathrm{~min}$. Formazan was extracted three times from dried, ground samples using $2 \mathrm{M} \mathrm{KOH}$ :chloroform (1:1, v/v) mixture. Chloroformic extracts were dried under gaseous nitrogen flush. The solid formazan residue was dissolved in DMSO-2 M $\mathrm{KOH}(1.6: 1, \mathrm{v} / \mathrm{v})$ mixture and measured with a Uvikon XL (Secomam, Alés Cedex, France) spectrophotometer at $630 \mathrm{~nm}$. The calibration curves were obtained by standard solutions of formazan produced and purified in vitro, which was adjusted further with the amount of retained formazan by cellulose matrix. The $\mathrm{O}_{2}{ }^{\bullet-}$ content of leaves was estimated by its reaction yield with the dye: four electrons/mol of reduced diformazan were generated during the process.

\section{Determination of Photosynthetic Gas Exchange, Chlorophyll a Fluorescence and PSI Absorbance Parameters}

Steady-state $\mathrm{CO}_{2}$ assimilation rate $\left(\mathrm{A}_{\mathrm{N}}\right)$ and stomatal conductance to water vapour $\left(\mathrm{g}_{\mathrm{sw}}\right)$ were measured from
9 a.m. to 13 p.m. using an LI-6400 portable photosynthesis analysing system (Li-Cor, Lincoln, NE, USA) equipped with an infrared gas analyzer. Leaf temperature was maintained at $25{ }^{\circ} \mathrm{C}$, the flow rate of air (containing $450 \mu \mathrm{mol} \mathrm{s}{ }^{-1} \mathrm{CO}_{2}$ from exogenous source) and PPFD were set at $300 \mu \mathrm{mol} \mathrm{s}{ }^{-1}$, and $221 \mu \mathrm{mol} \mathrm{m} \mathrm{m}^{-2} \mathrm{~s}^{-1}$, respectively. The intercellular $\mathrm{CO}_{2}$ concentration $(\mathrm{Ci})$ and its ratio to atmospheric $\mathrm{CO}_{2}$ level $\left(\mathrm{C}_{\mathrm{i}} / \mathrm{C}_{\mathrm{a}}\right)$ were also calculated. Each measurement was performed three times on three different plants. The whole experiment was also repeated three times (Poór et al. 2011).

Chlorophyll $a$ (Chl $a)$ fluorescence and PSI (P700) absorbance changes were monitored simultaneously with a (DUAL-PAM-100, Heinz-Walz, Effeltrich, Germany) fluorometer using measuring heads DUAL-E and DUALDR (Klughammer and Schreiber 2008). Briefly, after 30 min of dark adaptation, the modulated measuring beam (5 $\mu \mathrm{mol} \mathrm{m} \mathrm{m}^{-2} \mathrm{~s}^{-1}$ ) was turned on and the minimal fluorescence level in dark-adapted state $\left(F_{\mathrm{o}}\right)$ was determined. Then, the maximal fluorescence level of dark-adapted state $\left(F_{\mathrm{m}}\right)$ was measured by applying $14,000 \mu \mathrm{mol} \mathrm{m} \mathrm{m}^{-2} \mathrm{~s}^{-1}$ pulse of saturating light. The leaves were then illuminated continuously with $216 \mu \mathrm{mol} \mathrm{m} \mathrm{m}^{-2} \mathrm{~s}^{-1}$ actinic light. After $13 \mathrm{~min}$, the light-adapted steady-state fluorescence $\left(F_{\mathrm{s}}\right)$ was recorded and the maximum fluorescence level $\left(F_{\mathrm{m}}^{\prime}\right)$ was determined with saturating pulses. The minimum fluorescence level in the light-adapted state $\left(F_{\mathrm{o}}^{\prime}\right)$ was determined by illuminating the leaf with 3 -s farred light $\left(5 \mu \mathrm{mol} \mathrm{m} \mathrm{m}^{-2} \mathrm{~s}^{-1}\right)$ during a transient absence of actinic light. The following parameters were calculated by Dual PAM software: maximal quantum yield of PSII photochemistry, $F_{\mathrm{v}} / F_{\mathrm{m}}$, actual quantum yield of PSII electron transport in the light-adapted state $Y(\mathrm{II}), Y(\mathrm{NO})$ and $Y(\mathrm{NPQ})$, which represent the fraction of energy dissipated in form of heat via the non-regulated and regulated NPQ processes, respectively. The open fraction of PSII reaction centres was also determined $\left(q_{\mathrm{L}}\right)$ (Lei et al. 2014).

P700 redox changes were monitored by the 830 and $875 \mathrm{~nm}$ measuring beam difference signal following the method of Klughammer and Schreiber (2008). After $F_{\mathrm{o}}$ and $F_{\mathrm{m}}$, the maximal P700 signal $\left(P_{\mathrm{m}}\right)$ was determined immediately. After 13 min of actinic illumination, $P_{\mathrm{m}}^{\prime}$ was determined by a saturation pulse. The quantum yield of PSI $[Y(\mathrm{I})]$ was calculated by Dual PAM software using the equation $Y(\mathrm{I})=1-Y(\mathrm{ND})-Y(\mathrm{NA})$, where $Y(\mathrm{ND})$ and $Y(\mathrm{NA})$ are the quantum yields of non-photochemical energy dissipation in PSI due to donor and acceptorside limitations, respectively. $Y(\mathrm{ND})=1-\mathrm{P} 700_{\text {red }}$ and $Y(N A)=\left(P_{m}-P_{m}^{\prime}\right) / P_{m}$. We estimated the extent of cyclic electron flow around PSI (CEF) by the following equation: $Y(\mathrm{CEF}) / Y(\mathrm{II})=[Y(\mathrm{I})-Y(\mathrm{II})] / Y(\mathrm{II})$ (Zhang et al. 2014). Analysis of photosynthetic pigments was performed according to Wellburn and Lichtenthaler (1984). 


\section{Determination of Soluble Sugars}

Soluble sugars were extracted with $5 \mathrm{~mL}$ of $2 \mathrm{mM}$ HEPES buffer $(\mathrm{pH} 7.5$ ) in $80 \%$ ethanol from $0.5 \mathrm{~g}$ of fresh plant material frozen in liquid $\mathrm{N}_{2}$. After centrifugation $(15,000 \times g$, $4{ }^{\circ} \mathrm{C}, 30 \mathrm{~min}$ ), the pellet was extracted again with $5 \mathrm{~mL}$ of the same buffer and the combined supernatant was evaporated to dryness under vacuum at $45^{\circ} \mathrm{C}$. The dried samples were dissolved in $3 \mathrm{~mL}$ of distilled water in the presence of $0.3 \mathrm{~g}$ polyvinylpyrrolidone. Total sugar content was determined by the phenol-sulphuric acid method (Dubois et al. 1956). Sucrose, glucose, fructose as well as sorbitol contents were measured by Boehringer Mannheim/R Biopharm (Germany) sugar and D-sorbitol analysis kits (Cat. No. 10 716260035 for sucrose/D-glucose/D-fructose and Cat. No. E 0670057 for Sorbitol) according to the manufacturer's instructions as described by Poór et al. (2011) and Tari et al. (2010), respectively.

\section{Statistical Analysis}

Statistical analyses were performed with Sigma Plot 11.0 software (Systat Software Inc., Erkrath, Germany) using Duncan's multiple range test after analysis of variance (ANOVA) or Student's $t$ test and differences were considered significant if $P \leq 0.05$.

\section{Results}

\section{ET Production and Growth of Plants Exposed to ACC}

Exogenous ACC was converted to ET and elicited a concentration-dependent ET production in the root and an increased ET emanation at higher concentration from the leaf tissues of tomato, which, with the exception of samples treated with $100 \mu \mathrm{M}$ ACC, proved to be significantly higher in the root than in the leaves (Fig. 1).

Although ET may control plant growth, and higher ACC concentrations promoted fresh mass accumulation in shoots, these changes were not significant. Similar results were obtained for shoot and root elongation. However, we found significant increases in DW of shoots at $0.01 \mu \mathrm{M}$ or $1 \mu \mathrm{M}$, and significant reduction at $100 \mu \mathrm{M}$ ACC (Table 1). It has to be mentioned that $100 \mu \mathrm{M}$ ACC induced epinasty of leaf petioles.

\section{Potassium Uptake and Ion Content of ACC-Treated Plants}

The $\mathrm{K}^{+} /{ }^{86} \mathrm{Rb}^{+}$uptake assay was conducted with 3-week-old plants. Contrasting tendencies for ${ }^{86} \mathrm{Rb}^{+}$accumulation were found in shoots (Fig. 2a) and in roots (Fig. 2b) and small

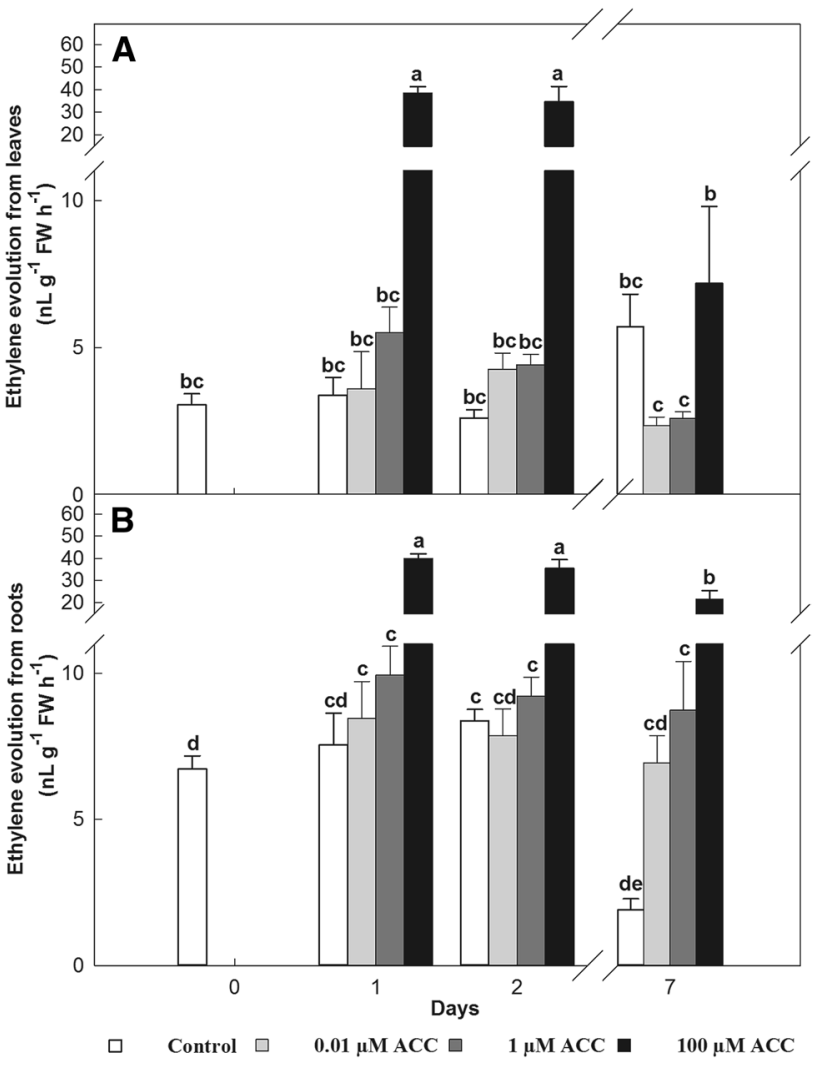

Fig. 1 ET production of leaves (a) and roots (b) of tomato plants exposed to 0.01 (grey bars), 1.0 (deep grey bars) and $100 \mu \mathrm{M} \mathrm{ACC}$ (black bars). Untreated controls: open bars. Results are means \pm SE, $n=4$. Values denoted with different letters show significant differences at $P \leq 0.05$ level (Duncan test)

differences can be detected if ACC was applied simultaneously with the isotope (black bars, direct effect) or in pretreatment (grey bars, after-effect).

Unexpectedly, exogenous ACC treatment caused a significant and concentration-dependent reduction in $\mathrm{K}^{+} /{ }^{86} \mathrm{Rb}^{+}$ uptake in the roots, which showed similar tendencies in both experimental systems. However, $\mathrm{K}^{+/ 86} \mathrm{Rb}^{+}$accumulation almost doubled at $0.01 \mu \mathrm{M}$ ACC in the shoot but it was unaffected compared to the untreated control at $100 \mu \mathrm{M}$ when ACC was applied in parallel with ${ }^{86} \mathrm{Rb}^{+}$. This suggests that low ACC could cause a shift in $\mathrm{K}^{+} /{ }^{86} \mathrm{Rb}^{+}$distribution between roots and shoot, whereas the inhibition of potassium uptake can be observed at $100 \mu \mathrm{M}$. If ACC was applied prior to $\mathrm{K}^{+} / 86 \mathrm{Rb}^{+}$uptake assay, in contrast to roots, there was no effect in the shoots. This means that ACC significantly reduced potassium uptake if it was applied as a pre-treatment.

In contrast to the short-term uptake experiments, after long-term ACC treatments, $\mathrm{K}^{+}$contents were not significantly different in the roots, but they were reduced in the leaves, which proved to be significant at 0.01 and $1.0 \mu \mathrm{M}$ ACC (Table 2). Unexpectedly, $\mathrm{Na}^{+}$accumulation increased 
Table 1 Changes in growth parameters [length, fresh (FW) and DW] in tomato roots and shoots 7 days after treatment with $0.01,1.0$ and $100 \mu \mathrm{M}$ ACC

\begin{tabular}{|c|c|c|c|c|c|c|c|c|}
\hline & \multicolumn{4}{|l|}{ Roots } & \multicolumn{4}{|l|}{ Shoots } \\
\hline & \multicolumn{8}{|l|}{$\operatorname{ACC}(\mu \mathrm{M})$} \\
\hline & Control & 0.01 & 1.0 & 100 & Control & 0.01 & 1.0 & 100 \\
\hline Length $(\mathrm{cm})$ & $22.83 \pm 0.7^{\mathrm{ns}}$ & $22.33 \pm 0.2^{\mathrm{ns}}$ & $23.67 \pm 1.1^{\mathrm{ns}}$ & $24.17 \pm 0.2^{\mathrm{ns}}$ & $21.25 \pm 0.7^{\mathrm{ns}}$ & $21.58 \pm 0.7^{\mathrm{ns}}$ & $22.00 \pm 0.6^{\mathrm{ns}}$ & $22.92 \pm 1.3^{\mathrm{ns}}$ \\
\hline FW $(\mathrm{g})$ & $5.68 \pm 0.2^{\mathrm{ns}}$ & $5.42 \pm 0.4^{\mathrm{ns}}$ & $4.98 \pm 0.2^{\mathrm{ns}}$ & $5.26 \pm 0.3^{\mathrm{ns}}$ & $12.11 \pm 1.2^{\mathrm{ns}}$ & $11.27 \pm 1.2^{\mathrm{ns}}$ & $13.41 \pm 1.5^{\mathrm{ns}}$ & $14.04 \pm 1.7^{\mathrm{ns}}$ \\
\hline $\mathrm{DW}(\mathrm{g})$ & $0.36 \pm 0.0^{\mathrm{ns}}$ & $0.34 \pm 0.0^{\mathrm{ns}}$ & $0.31 \pm 0.0^{\mathrm{ns}}$ & $0.30 \pm 0.0^{\mathrm{ns}}$ & $1.40 \pm 0.0^{\mathrm{c}}$ & $1.60 \pm 0.0^{\mathrm{a}}$ & $1.50 \pm 0.0^{\mathrm{b}}$ & $1.20 \pm 0.0^{\mathrm{d}}$ \\
\hline
\end{tabular}

The results are means \pm SE, $n=10$. Values denoted with different letters show significant differences at $P \leq 0.05$ level inside the groups (Duncan test)

$n s$ not significant

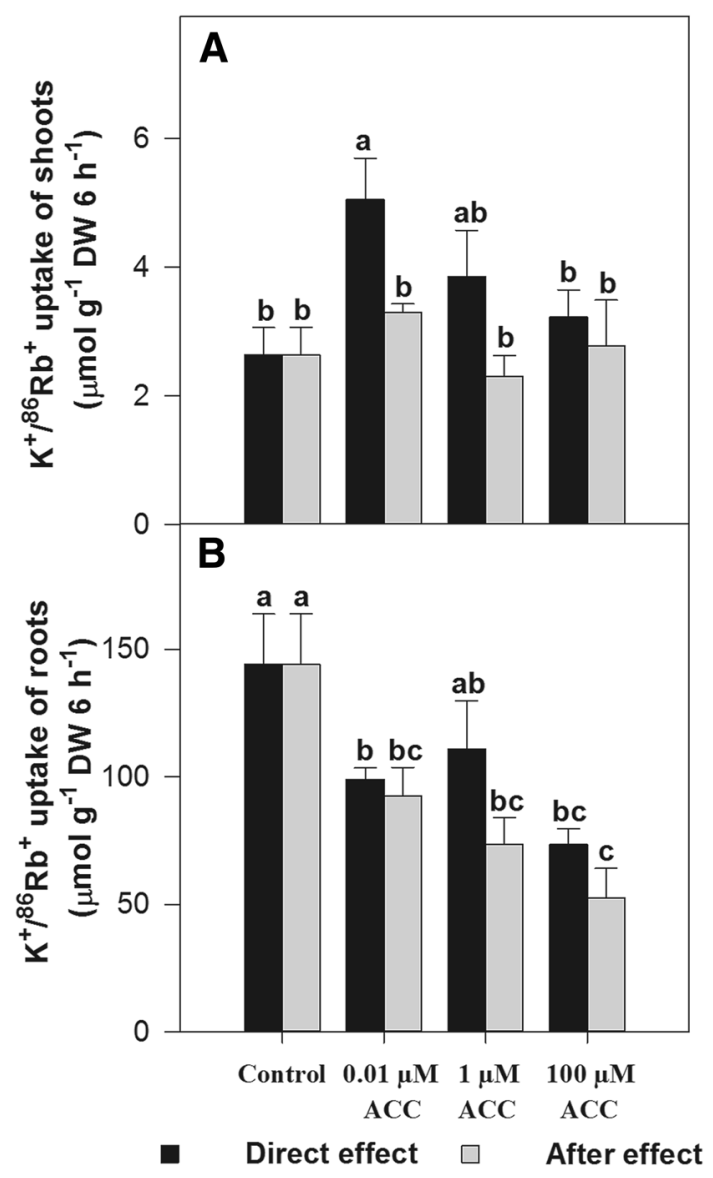

Fig. 2 Effect of exogenous ACC at $0.01,1.0$ and $100 \mu \mathrm{M}$ concentrations on $\mathrm{K}^{+} / 86 \mathrm{Rb}^{+}$uptake in the shoots (a) and in the roots (b) of tomato plants. Black bars: direct effect; Grey bars: after-effect. Results are means $\pm \mathrm{SE}, n=3$. Values denoted with different letters show significant differences at $P \leq 0.05$ level (Duncan test)

upon 1.0 and $100 \mu \mathrm{M}$ ACC treatment in the roots and at $100 \mu \mathrm{M}$ ACC in the leaves. Thus, the exposure of roots to higher ACC concentrations led to decreased $\mathrm{K}^{+} / \mathrm{Na}^{+}$ratios in both plant parts.
Similar tendencies can be found in $\mathrm{Mg}^{2+}$ accumulation: it was enhanced at $100 \mu \mathrm{M}$ ACC in the root system but the $\mathrm{Mg}^{2+}$ content of leaves declined at 0.01 and $1.0 \mu \mathrm{M}$. We could not detect significant changes in $\mathrm{Ca}^{2+}$ content but we found increments in the accumulation of $\mathrm{Fe}^{2+}$ in the presence of ACC in the roots and small but not significant decreases in leaf tissues.

\section{Generation of Reactive Oxygen and Nitrogen Species in Root Tips and in Fully Expanded Leaves}

Previous studies revealed that the ET-regulated responses are associated with changes in ROS and RNF levels. $\mathrm{H}_{2} \mathrm{O}_{2}$ contents increased to a small but significant extent upon all ACC treatments, but superoxide anion radical, NO and $\mathrm{ONOO}^{-}$production increased only at the highest ACC concentration in the leaf tissues (Fig. 3). However, the increment in peroxynitrite was much smaller than the changes in NO (Fig. 3c, d).

Much pronounced changes could be detected in the root apices. $\mathrm{H}_{2} \mathrm{O}_{2}$ accumulated very significantly at $100 \mu \mathrm{M}$ ACC, whereas lower ACC concentrations reduced NO levels (Fig. $4 \mathrm{a}, \mathrm{c}$ ). $\mathrm{O}_{2}^{\bullet-}$ production displayed a concentration-dependent optimum at $1.0 \mu \mathrm{M}$, but due to high standard errors the differences were not significant, whereas $\mathrm{ONOO}^{-}$formation remained constant (Fig. 4b, d).

\section{Photosynthetic Activity of Plants Exposed to ACC}

The 0.1 and $1.0 \mu \mathrm{M}$ ACC concentrations caused only marginal changes in $\mathrm{g}_{\mathrm{sw}}$ during the treatment period, but $100 \mu \mathrm{M}$ ACC reduced $\mathrm{g}_{\mathrm{sw}}$ by almost $50 \%$ from the 24 th hour, which proved to be significant between the 2 nd and 5 th days. (Fig. 5a). Ci/Ca exhibited similar tendencies as $\mathrm{g}_{\mathrm{sw}}$ in the first 2 days, but some differences could be observed from day 3 (Fig. 5b). The $100 \mu \mathrm{M}$ ACC treatment reduced $\mathrm{Ci} / \mathrm{Ca}$ from the first $24 \mathrm{~h}$ and interestingly, at day 3, we detected an increment in $\mathrm{Ci} / \mathrm{Ca}$ followed by a subsequent decline and later by an adjustment to control values. 
Table 2 Changes in the content of macroelements and iron $\left(\mu \mathrm{mol} \mathrm{g}{ }^{-1} \mathrm{DW}\right)$ in tomato roots and leaves 7 days after treatment with $0.01,1.0$ or $100 \mu \mathrm{M}$ ACC

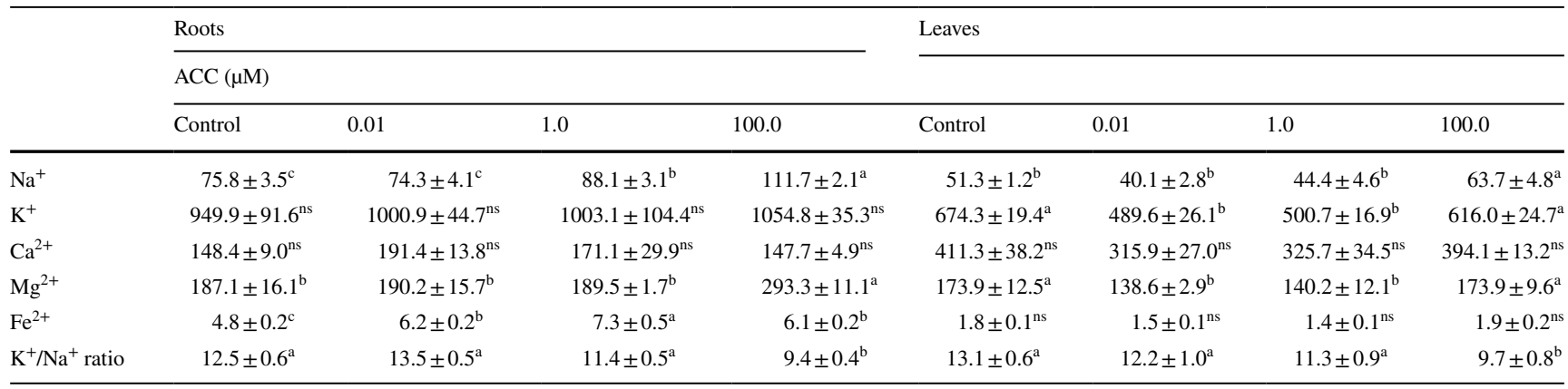

Results are means $\pm \mathrm{SE}, n=6$. Values denoted with different letters show significant differences inside the groups $(P \leq 0.05$, Duncan test $)$ $n s$ not significant

Fig. 3 Changes in $\mathrm{H}_{2} \mathrm{O}_{2}$ (a), $\mathrm{O}_{2}^{\cdot-}$ (b), $\mathrm{NO}(\mathbf{c})$ and $\mathrm{ONOO}^{-}$ (d) levels in tomato leaves prepared from untreated controls (open bars) and from plants exposed to 0.01 (grey bars), 1.0 (deep grey bars) and $100 \mu \mathrm{M}$ ACC (black bars). NO and $\mathrm{ONOO}^{-}$levels were added as a percent of control values. Results are means \pm SE, $n=16$ Values denoted with different letters show significant differences $(P \leq 0.05$, Duncan test)

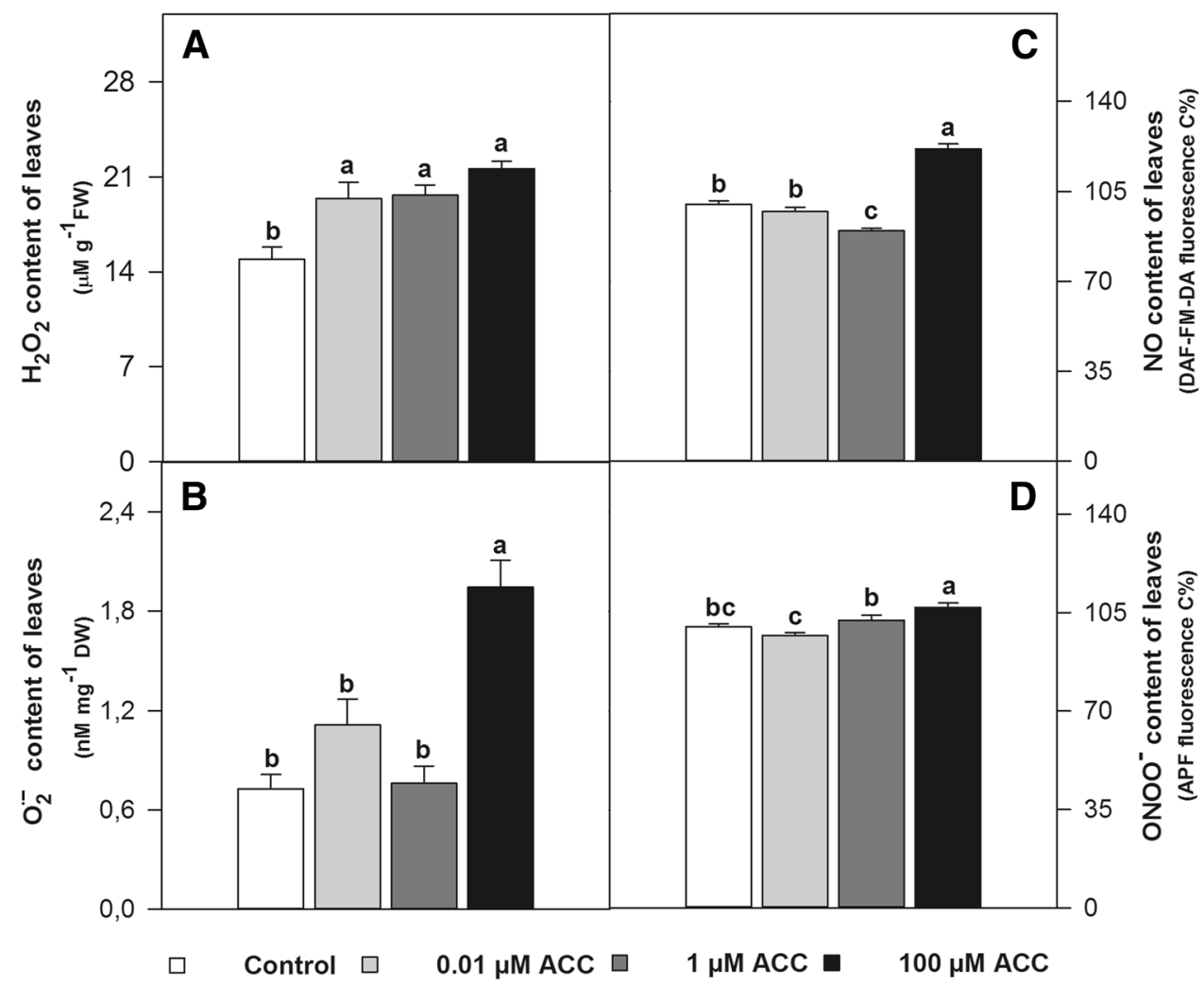

The 0.01 and $1.0 \mu \mathrm{M}$ ACC concentrations significantly increased $\mathrm{A}_{\mathrm{N}}$ between 24 and $48 \mathrm{~h}$, but $100 \mu \mathrm{M}$ ACC caused a significant, constant decrease in this parameter with the lowest value at day 3 and a recovery-like increase from day 4, which also started to decline during the last 2 days of treatment interval (Fig. 5c).

ACC treatments did not affect $\mathrm{F}_{\mathrm{V}} / \mathrm{F}_{\mathrm{M}}$ parameter of PSII significantly (Fig. 5d). However, $0.01 \mu \mathrm{M}$ ACC caused a transient increase in $\mathrm{F}_{0}$ after $48 \mathrm{~h}$ and $100 \mu \mathrm{M}$ ACC caused a significant decrease in this parameter at day 5 compared to control (Fig. 5e). Interestingly, both 0.01 and $100 \mu \mathrm{M}$ ACC reduced $\mathrm{q}_{\mathrm{L}}$, but it was more pronounced in the case of high ACC treatment (Fig. 5f).

Low ACC concentrations caused a small, stepwise increase in PSI actual quantum yield, $Y(\mathrm{I})$, but surprisingly, these changes were not accompanied with similar changes in PSII actual quantum yield ( $Y($ III)) (Fig. 6a, d). However, $100 \mu \mathrm{M}$ ACC significantly decreased $Y$ (II) compared to control from day 1 , this was accompanied with a slight but not significant decrease in $Y(\mathrm{I})$. Small fluctuations were detected in $Y(\mathrm{ND})$ and $Y(\mathrm{NA})$ after ACC treatment throughout the experiment (Fig. $6 \mathrm{~b}, \mathrm{c}$ ). One of the most important 
Fig. 4 Changes in $\mathrm{H}_{2} \mathrm{O}_{2}$ (a), $\mathrm{O}_{2}{ }^{\bullet-}$ (b), $\mathrm{NO}(\mathbf{c})$ and $\mathrm{ONOO}^{-}$ (d) levels in tomato root apices prepared from untreated controls (open bars) and from plants exposed to 0.01 (grey bars), 1.0 (deep grey bars) and $100 \mu \mathrm{M}$ ACC (black bars).

Fluorescence levels were added as a percent of control values. Results are means \pm SE, $n=16$. Values denoted with different letters show significant differences $(P \leq 0.05$, Duncan test). $\mathrm{ns}=$ not significant

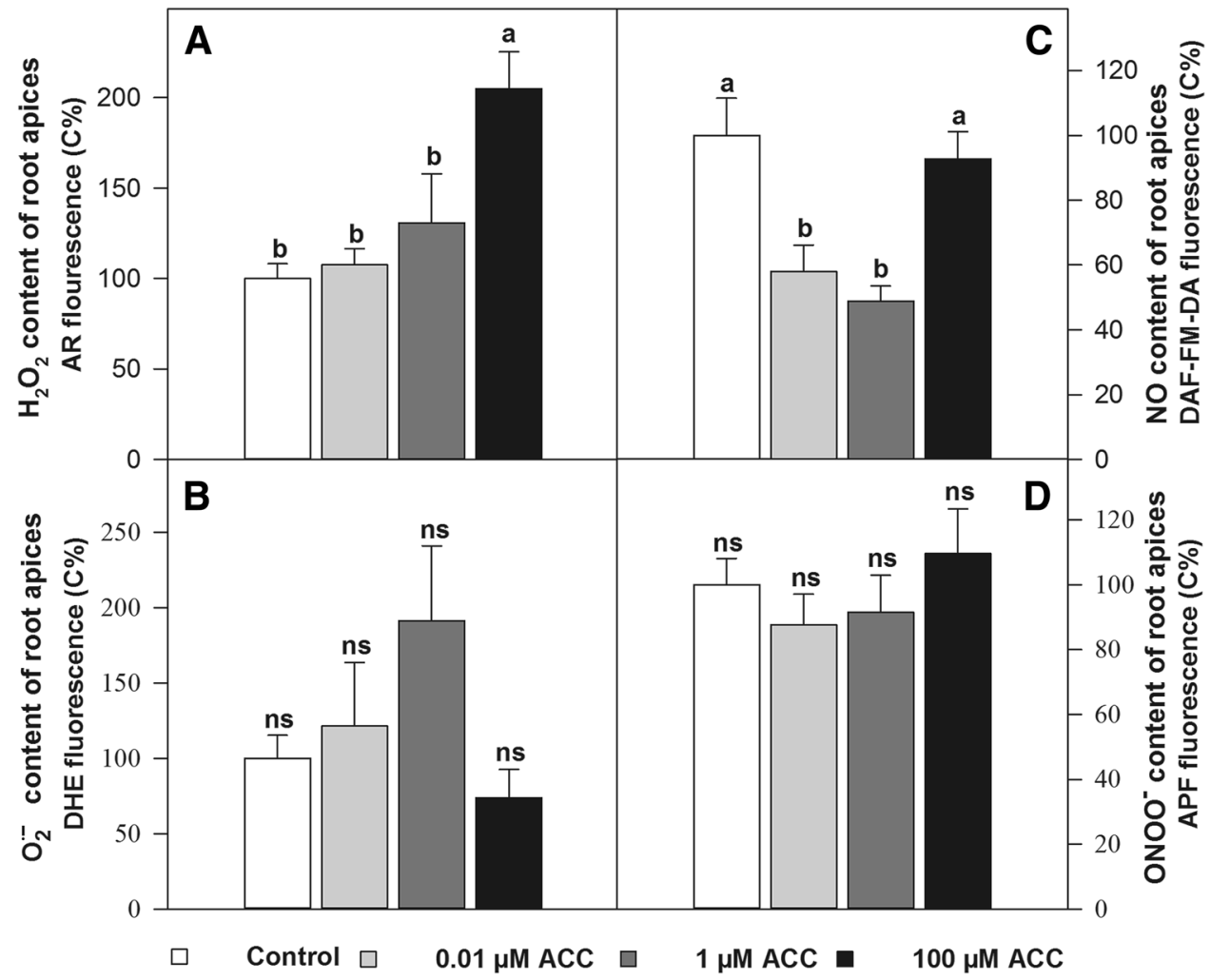

was only a twofold increase. Sucrose content was significantly enhanced by 0.01 ACC in the leaves, whereas 1.0 and $100 \mu \mathrm{M}$ ACC reduced root sucrose accumulation. All ACC concentrations enhanced sorbitol contents of tissues with the exception of $100 \mu \mathrm{M}$ ACC in the roots.

\section{Discussion}

Exogenous ACC applied via the root system of tomato was readily converted to ET during long-term experiments. ACC at low, 0.01 and $1.0 \mu \mathrm{M}$ concentrations caused smaller increases in ET in the roots, which can be observed under moderate stress, whereas $100 \mu \mathrm{M}$ ACC resulted in a more substantial increment in both plant parts, which can be measured under severe stress. These values and tendencies are in good agreement with those of Wang and Arteca (1992), who detected about $2.5 \mathrm{~nL} \mathrm{~h}^{-1} \mathrm{~g}^{-1}$ ET emanation from the leaves and about $6.0 \mathrm{~nL} \mathrm{~h}^{-1} \mathrm{~g}^{-1}$ from the roots of 7-week-old tomato plants ( $S$. lycopersicum L. cv. Heinz) under control conditions while the ET emanation increased to $10-30 \mathrm{~nL}$ $\mathrm{h}^{-1} \mathrm{~g}^{-1}$ under oxygen deficiency. In spite of significant physiological changes, increases in ET emanation from the leaves were very small at low ACC concentrations suggesting that in these tissues ACC (or other compounds generated by ACC treatment) may act independently of ET. At the same 


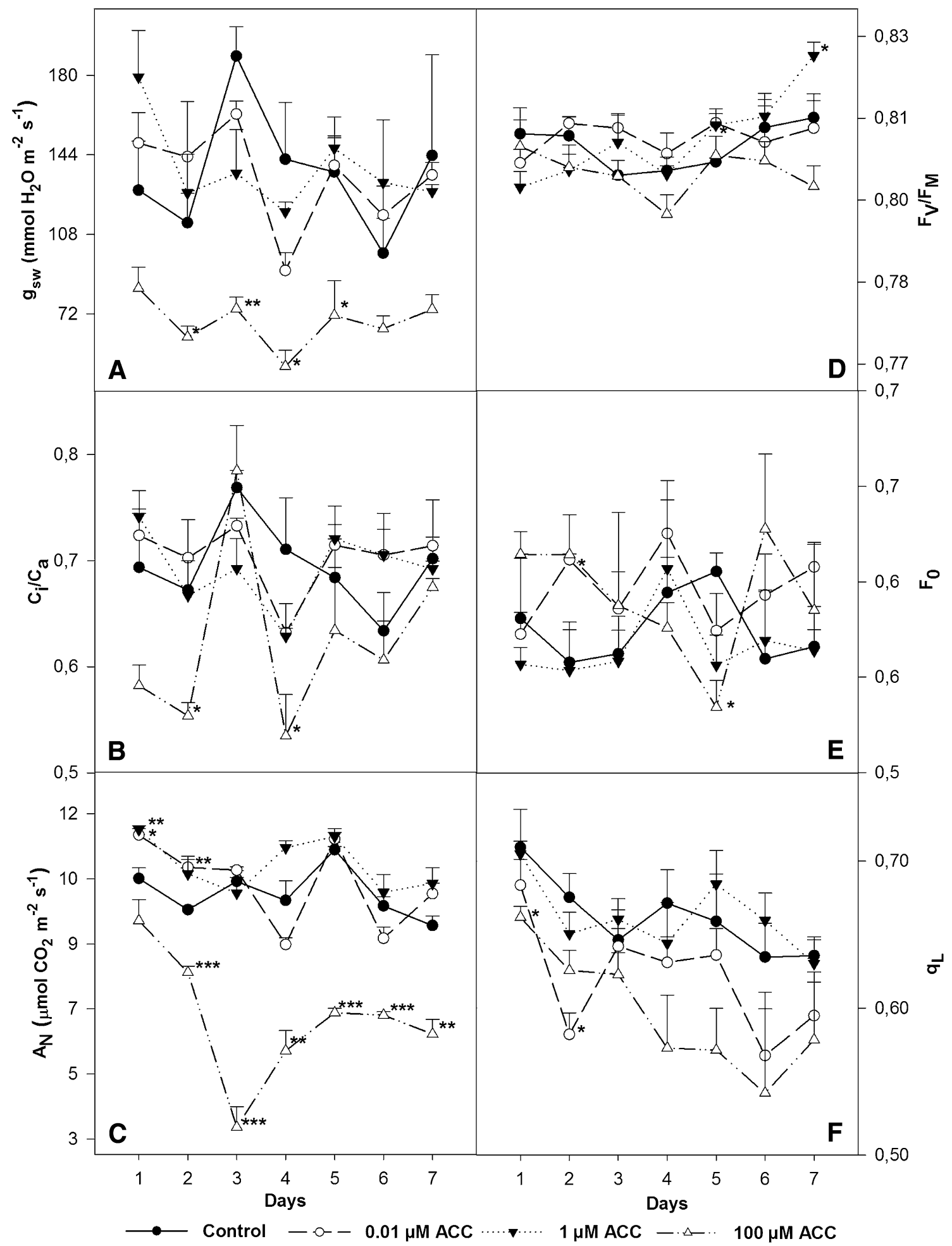

Fig. 5 Time course of changes in stomatal conductance to water vapour $\left(\mathrm{g}_{\mathrm{sw}}\right)(\mathbf{a})$, ratio of intercellular to atmospheric $\mathrm{CO}_{2}$ concentration $\left(\mathrm{C}_{\mathrm{i}} / \mathrm{C}_{\mathrm{a}}\right)(\mathbf{b})$, net assimilation rate of $\mathrm{CO}_{2}\left(\mathrm{~A}_{\mathrm{N}}\right)(\mathbf{c})$, maximal quantum yield of PSII $\left(\mathrm{F}_{\mathrm{V}} / \mathrm{F}_{\mathrm{M}}\right)(\mathbf{d})$, minimal fluorescence in the dark-adapted state $\left(\mathrm{F}_{0}\right)(\mathbf{e})$ and open fraction of PSII reaction centres $\left(\mathrm{q}_{\mathrm{L}}\right)(\mathbf{f})$ in control leaves (dark circle), and in leaves of tomato plants exposed to 0.01 (open circle), 1.0 (filled inverted triangle) and $100 \mu \mathrm{M}$ (triangle) ACC for 7 days. Results are means \pm SE $n=3$ (a, b, c) and $n=4(\mathbf{d}, \mathbf{e}, \mathbf{f})$. Data denoted by ${ }^{*, * *}$ and ${ }^{* * *}$ are significantly different from the untreated control of the given day at $P \leq 0.05, P \leq 0.01$ and $P \leq 0.001$ levels (Student's $t$ test) 


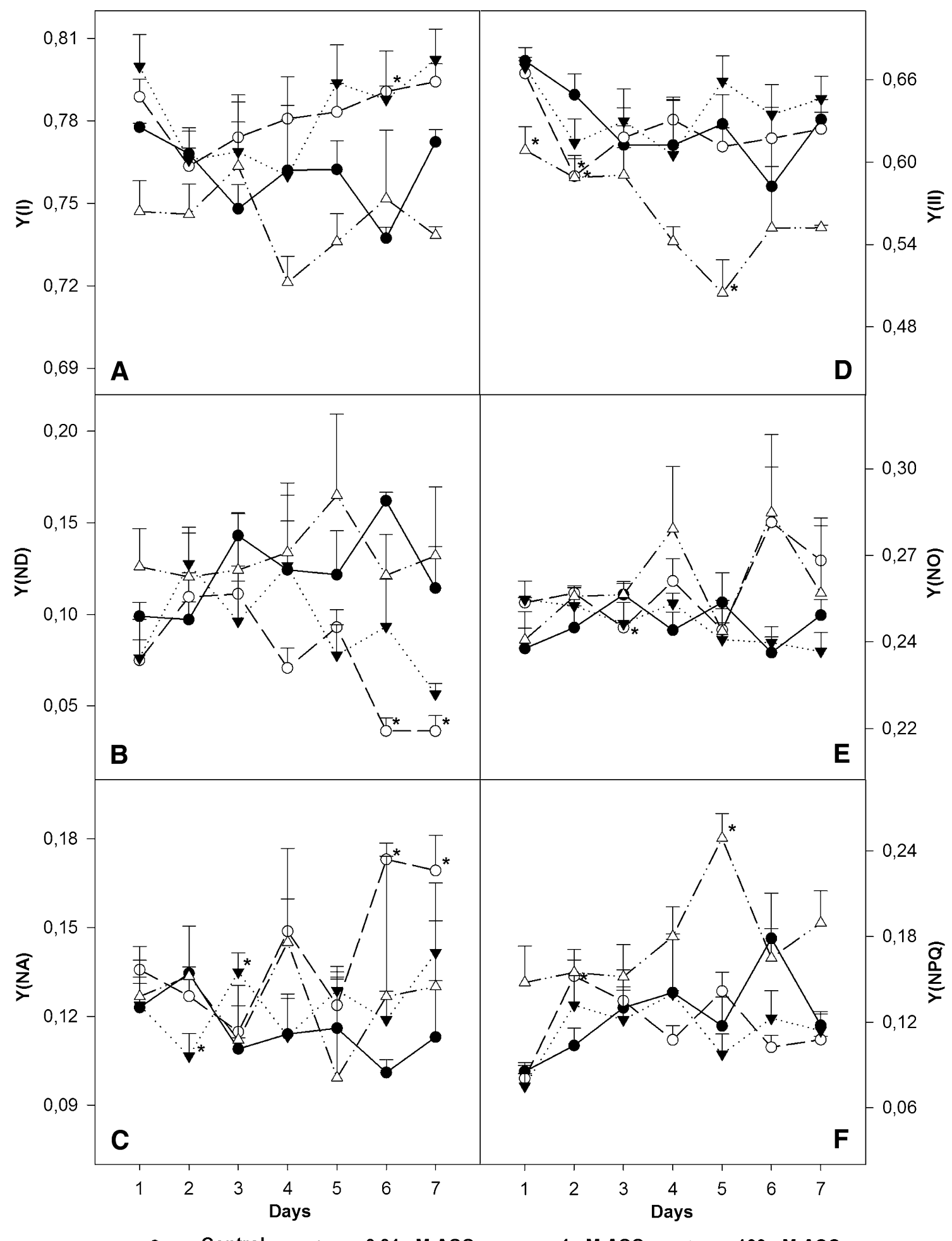

Fig. 6 Time course of changes in P700 absorbance (a, b, c) and Chl $a$ fluorescence parameters $(\mathbf{d}, \mathbf{e}, \mathbf{f})$ in control leaves (dark circle) and in leaves of tomato plants exposed to 0.01 (open circle), 1.0 (filled inverted triangle) and $100 \mu \mathrm{M}$ (triangle) ACC for 7 days. a Photochemical energy utilization of PSI; b non-photochemical energy dissipation due to donor-side limitation, $Y(\mathrm{ND})$; $\mathbf{c}$ non-photochemical energy dissipation due to acceptor-side limitation, $Y(\mathrm{NA})$ d effective quantum yield of PSII; e non-regulated energy dissipation, $Y(\mathrm{NO})$; $\mathbf{f}$ regulated (light-activated) energy dissipation, $Y(\mathrm{NPQ})$. Results are means $\pm \mathrm{SE}, n=4$. Data denoted by $*$ are significantly different from the untreated control of the given day at $P \leq 0.05$ level (Student's $t$ test, $n=4)$ 


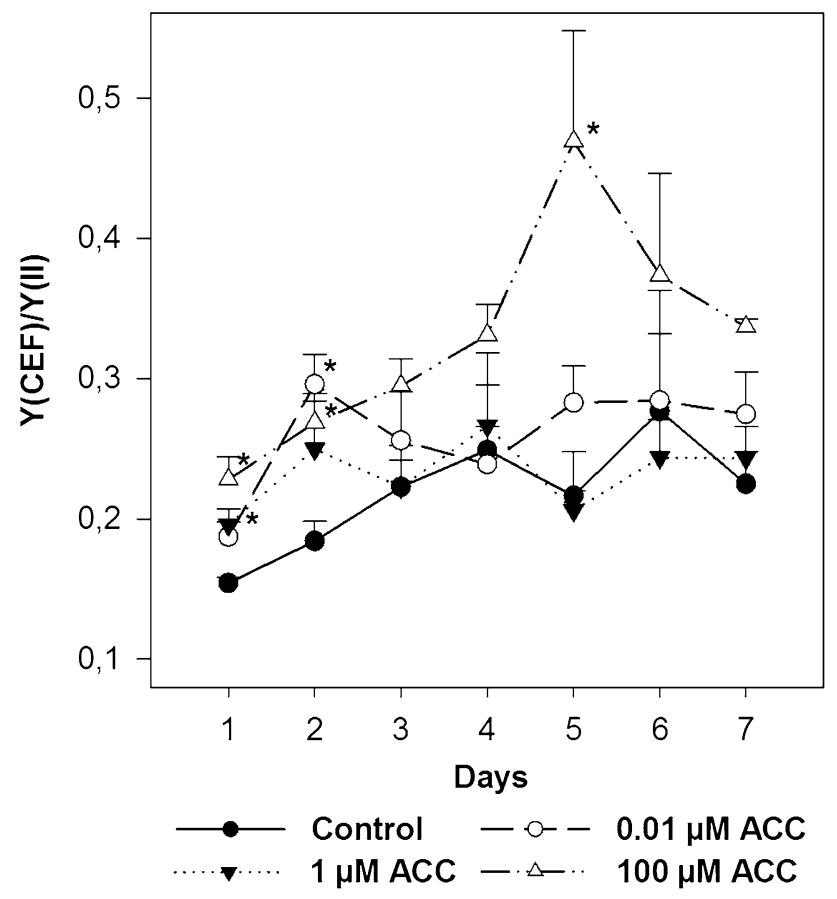

Fig. 7 Time course of changes in the extent of CEF around PSI in control leaves (dark circle) and in leaves of tomato plants exposed to 0.01 (open circle), 1.0 (filled inverted triangle) and $100 \mu \mathrm{M}$ (triangle) ACC for 7 days. Results are means \pm SE, $n=4$. Data denoted by ${ }^{*}$ are significantly different from the untreated control at the given day at $P \leq 0.05$ level (Student's $t$ test)

Table 3 Changes in chlorophyll and total carotenoid (Car) content $\left(\mathrm{mg} \mathrm{g}^{1} \mathrm{FW}\right)$ in tomato leaves 7 days after treatment with $0.01,1.0$ and $100 \mu \mathrm{M}$ ACC

\begin{tabular}{lllll}
\hline \multirow{4}{*}{} & ACC $(\mu \mathrm{M})$ & & \\
\cline { 2 - 5 } & Control & 0.01 & 1.0 & 100 \\
\hline Chl $a$ & $1.69 \pm 0.06^{\mathrm{ns}}$ & $1.78 \pm 0.03^{\mathrm{ns}}$ & $1.89 \pm 0.10^{\mathrm{ns}}$ & $1.56 \pm 0.18^{\mathrm{ns}}$ \\
Chl $b$ & $0.62 \pm 0.02^{\mathrm{ns}}$ & $0.63 \pm 0.02^{\mathrm{ns}}$ & $0.70 \pm 0.05^{\mathrm{ns}}$ & $0.58 \pm 0.07^{\mathrm{ns}}$ \\
Chl $a+b$ & $2.31 \pm 0.08^{\mathrm{ns}}$ & $2.41 \pm 0.04^{\mathrm{ns}}$ & $2.59 \pm 0.14^{\mathrm{ns}}$ & $2.14 \pm 0.25^{\mathrm{ns}}$ \\
Car & $0.44 \pm 0.01^{\mathrm{ab}}$ & $0.46 \pm 0.01^{\mathrm{a}}$ & $0.48 \pm 0.02^{\mathrm{a}}$ & $0.39 \pm 0.03^{\mathrm{b}}$ \\
\hline
\end{tabular}

Results are means \pm SE. $n=3$. Values denoted with different letters show significant differences $(P \leq 0.05$, Duncan test)

$n s$ not significant

time, local ET production that reaches the physiologically active level in these tissues cannot be excluded.

The effect of exogenous ACC on growth parameters of tomato was negligible. There were no significant changes in the shoot and root length as a function of increasing ACC concentrations but some additional fresh weight accumulation can be observed in ACC-treated shoots compared to controls. However, in accordance with increased $\mathrm{CO}_{2}$ assimilation, the ACC-induced increases in shoot biomass were significant on the DW basis at lower ACC concentrations. Similar results were found for the enhancement of shoot growth after ACC treatment in tomato explants by Trujillo-Moya and Gisbert (2012).

It was observed first in our experiments that low ACC concentrations applied in parallel with $\mathrm{K}^{+} /{ }^{86} \mathrm{Rb}^{+}$uptake solution, resulted in a shift in $\mathrm{K}^{+} /{ }^{86} \mathrm{Rb}^{+}$distribution between roots and shoots, whereas inhibition of potassium uptake can be observed at $100 \mu \mathrm{M}$ ACC. This suggests that the effects of low or high concentrations of ACC on $\mathrm{K}^{+}$transport are different. Furthermore, ACC significantly reduced potassium uptake if it was applied as a pre-treatment. This may support the idea based on the results of Staal et al. (2011) that exogenous ACC may interfere with active potassium transport by modulating PM $\mathrm{H}^{+}$-ATP-ase activity.

Early studies revealed that ET interacted with both $\mathrm{K}^{+}$ deficiency and $\mathrm{Na}^{+}$toxicity by controlling $\mathrm{K}^{+} / \mathrm{Na}^{+}$homeostasis. Increased ET production was found in Arabidopsis under $\mathrm{K}^{+}$deficiency, which was followed by enhanced expression of the high-affinity $\mathrm{K}^{+}$transporter, AtHAK5 (Jung et al. 2009). However, ethephon, an ET-releasing compound could induce the expression of HAK5 under full nutrient conditions, too, suggesting that ET may control potassium uptake at the transcription level (Schachtman 2015).

Under salt stress, the callus culture of ET-receptor Arabidopsis mutants (etrl-3) deficient in ET signalling was more sensitive to excess of $\mathrm{Na}^{+}$, than the WT, which could be demonstrated by greater electrolyte leakage, lower $\mathrm{K}^{+} / \mathrm{Na}^{+}$ ratio and low PM $\mathrm{H}^{+}$-ATPase activity of the mutants. WT callus treated with exogenous ACC showed a higher $\mathrm{K}^{+} /$ $\mathrm{Na}^{+}$ratio, greater $\mathrm{PM} \mathrm{H}^{+}$-ATPase activity, and therefore, enhanced salt tolerance compared to control, which was not observed in ET-receptor mutant cultures (Wang et al. 2009). Unexpectedly, we found a contrasting effect in our system under full nutrient conditions. Exogenous ACC at high concentrations caused increased $\mathrm{Na}^{+}$accumulation and decreased $\mathrm{K}^{+} / \mathrm{Na}^{+}$ratio that may function as a moderate ionic stress in tomato tissues. These changes in the $\mathrm{K}^{+} /$ $\mathrm{Na}^{+}$ratio are small compared to those measured in plants growing in $100-200 \mathrm{mM} \mathrm{NaCl}$ in hydroponic culture. However, changes of a similar range can be observed in other experiments, when tomato plants growing in sandy loam were drip-irrigated with low and high concentrations of $\mathrm{NaCl}$ until fruit ripening (Saranga et al. 1993). This small decrease in $\mathrm{K}^{+} / \mathrm{Na}^{+}$ratio may have a beneficial effect in a subsequent osmotic/salt stress acclimation, thus it can be considered as a eustress caused by ACC.

Previous studies revealed that the ET-regulated responses are associated with changes in ROS and RNF levels. Although all of these reactive compounds can be toxic to plant tissues at appropriate concentrations, ROS and RNF may act as a signal regulating many physiological processes (Kocsy et al. 2013). In spite of ROS and RNF generation, 
Table 4 Total sugar content ( $\left.\mathrm{mg} \mathrm{g}^{-1} \mathrm{FW}\right)$ and the accumulation of different types of sugars $\left(\mu \mathrm{mol} \mathrm{g}^{-1} \mathrm{FW}\right) 7$ days after ACC treatments in tomato plants

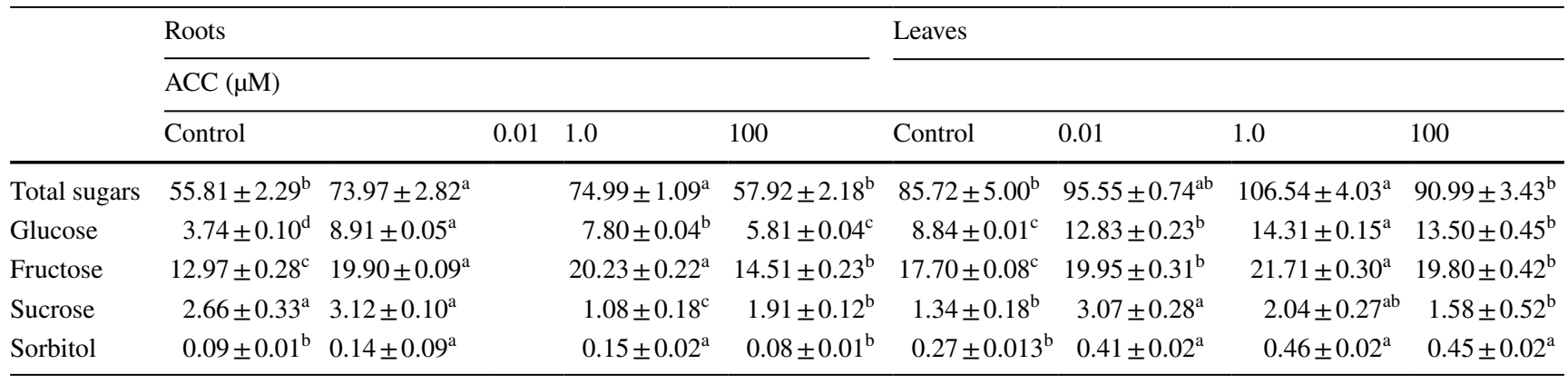

Results are means $\pm \mathrm{SE}, n=3$. Values denoted with different letters show significant differences inside the groups at $P \leq 0.05$ level (Duncan test)

plants could tolerate the increased ACC (ET) concentrations for 1 week as can be concluded from growth parameters. In the root apices, the generation of various forms of ROS can be measured within the $1 \mathrm{~cm}$ apical region of lateral roots. The increases in superoxide level were not significant and $\mathrm{H}_{2} \mathrm{O}_{2}$ content increased pronouncedly only at $100 \mu \mathrm{M}$ ACC in the roots. Because $\mathrm{NO}$ accumulation was inhibited at 0.1 and $1.0 \mu \mathrm{M}$ ACC, and it was maintained at the control level at $100 \mu \mathrm{M}$ ACC, cells in the root apices were not exposed to nitrosative stress. $\mathrm{H}_{2} \mathrm{O}_{2}$ accumulation at $100 \mu \mathrm{M} \mathrm{ACC}$, however, may participate in ET signalling to control $\mathrm{K}^{+}$homeostasis by the activation of the uptake (Schachtman 2015) or efflux systems (Ashley et al. 2005; Demidchik 2014; Shabala and Pottosin 2014).

Summarizing the current knowledge, the effects of ET/ ACC on photosynthesis seem to be contradictory. ET inhibits photosynthesis in most of the cases and it has no effect or enhances net $\mathrm{CO}_{2}$ fixation in others (Ceusters and Van de Poel 2018). ET released from exogenous ethephon and sprayed on the leaves of intact tomato plants caused extreme epinasty and the abscission of flower buds, but photosynthetic $\mathrm{CO}_{2}$ fixation, photorespiration, respiration and transpiration did not change after $24 \mathrm{~h}$ compared to control. However, ET affected the partitioning of $\mathrm{CO}_{2}$ assimilates in this system (Woodrow et al. 1988).

We also found time- and concentration-dependent changes in the photosynthetic activity of tomato after ACC treatments. The net $\mathrm{CO}_{2}$ fixation rate $\left(\mathrm{A}_{\mathrm{N}}\right)$ in parallel with $\mathrm{g}_{\mathrm{sw}}$ was significantly higher in plants treated with low concentrations of ACC after $24 \mathrm{~h}$. However, $\mathrm{g}_{\mathrm{sw}}$ did not show close correlation with $A_{N}$ generally with the exception of $100 \mu \mathrm{M}$ ACC treatment suggesting that other factors are also involved in the control of $\mathrm{A}_{\mathrm{N}}$. A similar observation was reported by Iqbal et al. (2011), who found that the enhancement of photosynthesis by ethephon application was associated with increases in $g_{\text {sw }}$ but later ET was able to control stomatal closure by increasing intercellular $\mathrm{CO}_{2}$ $\left[\mathrm{CO}_{2}\right]_{\mathrm{i}}$. This led to the uncoupling of $g_{\mathrm{sw}}$ and $\mathrm{A}_{\mathrm{N}}$ : first both increased together whereas increasing $\left[\mathrm{CO}_{2}\right]_{\mathrm{i}}$ decreased $g_{\mathrm{sw}}$.
The negative effect of high ET levels on $\mathrm{A}_{\mathrm{N}}$ in our experiments originated mainly from stomatal limitations during the first 2 days. After 3 days, however, $100 \mu \mathrm{M}$ ACC induced a higher contribution of non-stomatal factors to the limitation of $\mathrm{A}_{\mathrm{N}}$ (significant increment in $\mathrm{C}_{\mathrm{i}} / \mathrm{C}_{\mathrm{a}}$ ), but stomatal factors could have a greater importance again in the control of $A_{N}$ at the end of experiments.

Because $F_{V} / F_{M}$ was not significantly affected and a significant increase in $\mathrm{F}_{0}$ was not detected, exogenous ACC did not cause irreversible damage to PSII reaction centres. The $0.01 \mu \mathrm{M}$ ACC treatment caused an enhanced electron flow in PSI, which was accompanied with fluctuating responses of $A_{N}$ from day 3. For the end of the treatment period, this event caused a slight decline in PSI acceptor pool, as it can be concluded from a significant $Y(\mathrm{ND}) \rightarrow Y$ (NA) shift. Surprisingly, the increases in $Y(\mathrm{I})$ after treatments with low concentrations of ACC were not coupled with enhanced PSII activity in our system. We also found a transient activation of CEF and [ $Y(\mathrm{CEF}) / Y(\mathrm{II})]$ upon treatments with 0.01 and $1.0 \mu \mathrm{M}$ ACC on day 2. The ratio of $Y(\mathrm{CEF})$ to the quantum yield of PSII linear electron transport $[Y(\mathrm{CEF}) / Y(\mathrm{II})]$ has been introduced recently as a more expressive parameter for the estimation of cyclic electron transport rate around PSI (Zhang et al. 2014), we used this parameter throughout the experiments. Some increment in $Y(\mathrm{I})$ by $1.0 \mu \mathrm{M}$ ACC was also induced from day 4 . This is coupled with less pronounced $Y(\mathrm{ND}) \rightarrow Y(\mathrm{NA})$ shift and only marginal activation of $Y(\mathrm{CEF}) / Y(\mathrm{II})$. Beside its role in the development of photoprotective (NPQ), the CEF can also generate extra ATP for the $\mathrm{CO}_{2}$ fixation process and adjusts the ratio of ATP to $\mathrm{NADPH}$, thus it plays a crucial role in maintaining $\mathrm{A}_{\mathrm{N}}$ during stress conditions (Johnson 2011).

A substantial decrease occurred, however, in the effective quantum yield of PSII ( $Y(\mathrm{II}))$ and $q_{\mathrm{L}}$, which displays the fraction of open PSII reaction centres upon treatment with $100 \mu \mathrm{M}$ ACC, whereas the quantum yield of PSI $Y(\mathrm{I})$ declined only transiently. Because $Y(\mathrm{NO})$ showed only transient and small increases in these plants due to the increasing population of closed PSII reaction centres, it 
can be concluded that the damage to PSII itself was negligible and the excess energy absorbed by PSII was successfully dissipated as heat by significantly enhanced NPQ mechanisms or by the involvement of alternative electron acceptors (Krause and Weis 1991).

From day 5, we found significant induction of $Y(\mathrm{CEF}) / Y(\mathrm{II})$ by $100 \mu \mathrm{M}$ ACC, which after a maximum started to decrease. $Y(\mathrm{CEF})$ can facilitate the development of a proton electrochemical potential gradient in thylakoid membranes and through the generation of NPQ it may protect PSII from photoinhibition (Miyake et al. 2005). $Y(\mathrm{NPQ})$ is a strongly $\Delta \mathrm{pH}$-related parameter, however, after a concomitant maximum of $Y(\mathrm{NPQ})$ and $Y(\mathrm{CEF}) / Y(\mathrm{II})$, the $\Delta \mathrm{pH}$-dependent violaxanthin deepoxidation and safe alternative NPQ pathways failed to protect the photosynthetic apparatus efficiently by themselves, so increasing formation of reactive molecules were facilitated, which has not been scavenged totally. Molecular oxygen is a very important electron acceptor of the photosynthetic electron transport chain, which may lead to detrimental $\mathrm{O}_{2}{ }^{--}$accumulation in the absence of scavenging mechanisms. After a certain degree of stress, thylakoid membranes become more permeable to protons due to structural damage, which leads to the loss of $\Delta \mathrm{pH}$ and NPQ (Kalaji et al. 2017). Because ACC at $100 \mu \mathrm{M}$ stimulated the accumulation of $\mathrm{O}_{2}{ }^{--}, \mathrm{H}_{2} \mathrm{O}_{2}$, NO and $\mathrm{ONOO}^{-}$after 1 week (Fig. 3), the nitro-oxidative stress could facilitate damage to thylakoid membranes and decrease in $\Delta \mathrm{pH}$ and NPQ. At the same time, these reactive molecules can also induce antioxidant defence mechanisms.

In summary, exogenous ACC treatments did not cause irreversible damage to photosystems. The energy conversion of PSII was more sensitive to high ACC concentration than that of PSI, and the cyclic electron transport exhibited a time- and ACC concentration-dependent activation, which, together with heat dissipation could successfully protect the photosystems from photoinhibition. This is supported by the fact that there were no significant changes in the chlorophyll and carotenoid contents of the leaf tissues with the exception of $100 \mu \mathrm{M}$ ACC treatment, which caused a small decrease in carotenoids.

The accumulation of sugars, glucose, fructose and sucrose and that of the sugar alcohol, sorbitol increased in the leaves of treated plants compared to control in a concentration-dependent manner. The maximum of total sugars, glucose, fructose and sucrose content was found at $0.01-1.0 \mu \mathrm{M}$ ACC. These changes coincide well with the early activation of $\mathrm{CO}_{2}$ fixation and excess dry mass accumulation in ACC-treated plants. Similar tendencies can be found in the root sugar content with one important exception. The accumulation of sucrose, the transport form of sugars decreased in the root upon $1.0-100 \mu \mathrm{M}$
ACC treatment. This suggests that exogenous ACC facilitates changes in the availability and distribution of sugars between plant organs. Plants also accumulated sorbitol upon ACC treatment.

It was found by several authors that soluble sugars such as disaccharides, raffinose family oligosaccharides and fructans are strongly related to stress-induced ROS accumulation in plants (Keunen et al. 2013). Soluble carbohydrates may also be synthesised in response to osmotic stress acting as osmoprotectants that stabilise cellular membranes. At low concentrations, sugars might function as a substrate for metabolic enzymes or signals for stress-induced alterations but some of them, such as fructose, galactinol, raffinose family oligosaccharides, fructans and sugar alcohols are proven or suggested to function as antioxidants (Nishizawa et al. 2008; Peshev and Van den Ende 2013). Thus, the increased sugar content may alleviate oxidative stress during abiotic stress acclimation.

Recent findings have suggested that ACC may have an ET-independent role in plants (Yoon and Kieber 2013; Van de Poel and Van Der Straeten 2014), which cannot be ruled out in our system, too, in case of ion transport and photosynthetic electron transport. It was found that Arabidopsis feil fei 2 mutants defective in the production of leucine-rich repeat receptor kinases, FEI1 and FEI2 exhibited a severe defect in anisotropic root growth. The feil fei2 genotype can be reversed by the application of ET biosynthesis inhibitors, whereas the ET signalling inhibitors were not effective. These results suggest that ACC has an ET-independent role in the inhibition of root growth (Xu et al. 2008). Moreover, ACC led to the inhibition of root epidermal cell elongation in both WT- and ET-insensitive ein 3 eil-1 mutants, however, ET-signalling components were required for long-term ACC responses (Tsang et al. 2011). Keeping in mind that ACC per se may function as a signal, the uptake of ACC in are-2 mutants deficient in LHT1 amino acid transporter, displayed an ACC concentration-dependent effect on root growth (Shin et al. 2015). At low ACC concentration $(1.0 \mu \mathrm{M})$, the authors found a clear difference in ACC-induced root growth reduction between WT and mutant plants, which were insensitive to exogenous ACC, while this difference disappeared at $10 \mu \mathrm{M}$ ACC. This suggests that ET induced by high exogenous ACC may have an additional influence on root growth in are-2 mutants.

At the same time, it may raise the question of whether there are differences between the effects of low or high ACC concentrations on plant responses. In our experiments, we found very important differences between the effect of low and high $\mathrm{ACC}$ concentrations on the $\mathrm{K}^{+} /{ }^{86} \mathrm{Rb}^{+}$uptake, $\mathrm{CO}_{2}$ fixation rate, the effective quantum yield of PSI, $Y(\mathrm{ND})$ and $Y(\mathrm{NA})$ as well as on cyclic electron transport. Because we detected very low differences in ET production in plant tissues exposed to low ACC concentrations, further research 
is required to reveal the role of ACC signalling or the direct effect of ACC on these processes.

In conclusion, exogenous ACC in long-term experiments elicited specific changes compared to short-term effects in ion accumulation, photosynthesis and as a consequence, in the level and distribution of soluble carbohydrates between plant organs. These physiological changes can be considered as ET/ACC-induced eustress, which may contribute to abiotic stress resistance of plants.

Acknowledgements Open access funding provided by [University of Szeged (SZTE)]. We thank Etelka Bécsné for her excellent technical assistance. This work was funded by grants from the National Research, Development and Innovation Office (OTKA K 101243 and OTKA PD112855) and by the Hungary-Serbia IPA Cross-border Cooperation Programme (HUSRB/1203/221/173).

\section{Compliance with Ethical Standards}

Conflict of interest The authors declare that they have no conflict of interest.

OpenAccess This article is distributed under the terms of the Creative Commons Attribution 4.0 International License (http://creativeco mmons.org/licenses/by/4.0/), which permits unrestricted use, distribution, and reproduction in any medium, provided you give appropriate credit to the original author(s) and the source, provide a link to the Creative Commons license, and indicate if changes were made.

\section{References}

Abeles FB, Heggestad HE (1973) Ethylene: an urban air pollutant. J Air Pollut Control Assoc 23:517-521. https://doi.org/10.1080/00022 470.1973.10469798

Abeles FB. Morgan PW. Saltveit ME (1992) Regulation of ethylene production by internal, environmental and stress factors. In: Abeles FB, Morgan PW, Saltveit ME (eds) Ethylene in plant biology, 2nd edn. Academic Press, London, pp 54-262

Ashley MK, Grant M, Grabov A (2005) Plant responses to potassium deficiencies: a role for potassium transport proteins. J Exp Bot 57:425-436

Basiouny FM, Basiouny K, Maloney M (1994) Influence of water stress on abscisic acid and ethylene production in tomato under different PAR levels. J Hortic Sci 69:535-541

Bassi PK, Spencer MS (1983) Does light inhibit ethylene production in the leaves? Plant Physiol 73:758-760

Bournonville GCF, Diaz-Ricci JC (2010) Quantitative determination of superoxide in plant leaves using a modified NBT staining method. Phytochem Anal 22:268-271

Broekgaarden C, Caarls L, Vos IA, Corné MJ, Pieterse S, Van Wees CM (2015) Ethylene: traffic controller on hormonal crossroads to defense. Plant Physiol 169:2371-2379

Ceusters J, Van de Poel B (2018) Ethylene exerts species-specific and age-dependent control of photosynthesis. Plant Physiol 176:2601-2612

Chen Z, Gallie DR (2015) Ethylene regulates energy-dependent nonphotochemical quenching in Arabidopsis through repression of xanthophyll cycle. PLoS ONE 10(2):e0144209. https://doi. org/10.1371/journal.pone.0144209
Chung J-S, Zhu J-K, Bressan RA, Hasegawa PM, Shi H (2008) Reactive oxygen species mediate $\mathrm{Na}^{+}$-induced $\mathrm{SOS} 1 \mathrm{mRNA}$ stability in Arabidopsis. Plant J 53:554-565

Demidchik D (2014) Mechanisms and physiological roles of $\mathrm{K}^{+}$efflux from root cells. J Plant Physiol 171:696-707

Desikan R, Last K, Harriett-Williams R, Tagliavia C, Harter K, Hooley R, Hancock JT, Neill SJ (2006) Ethylene-induced stomatal closure in Arabidopsis occurs via AtrbohF-mediated hydrogen peroxide synthesis. Plant J 47:907-916

Dubois M, Gibbs KA, Hamilton JK, Roberts DA, Smith F (1956) Colorimetric methods for the determination of sugars and related substances. Anal Chem 28:350-352

Dubois M, Van den Broeck L, Inzé D (2018) The pivotal role of ethylene in plant growth. Trends Plant Sci 23:311-323. https:// doi.org/10.1016/j.tplants.2018.01.003

Else M, Hall KC, Arnold GM, Davies WJ, Jackson MB (1995) Export of abscisic acid, 1-aminocyclopropane-1-carboxylic acid, phosphate, and nitrate from roots to shoots of flooded tomato plants (accounting for effects of xylem sap flow rate on concentration and delivery). Plant Physiol 107:377-384

Grbic V, Bleecker AB (1995) Ethylene regulates the timing of leaf senescence in Arabidopsis. Plant J 8:595-602

Honma M, Shimomura T (1978) Metabolism of 1-aminocyclopropane-1-carboxylic acid. Agric Biol Chem 43:1825-1831

Iqbal N, Nazar R, Syeed S, Masood A, Khan NA (2011) Exogenously-sourced ethylene increases stomatal conductance, photosynthesis, and growth under optimal and deficient nitrogen fertilization in mustard. J Exp Bot 62:4955-4963

Iqbal N, Trivellini A, Masood A, Ferrante A, Khan NA (2013) Current understanding on ethylene signaling in plants: the influence of nutrient availability. Plant Physiol Biochem 73:128-138

Johnson NG (2011) Physiology of PSI cyclic electron transport in higher plants. Biochim Biophys Acta 1807:384-389

Jung J-Y, Shin R, Schachtman DP (2009) Ethylene mediates response and tolerance to potassium deprivation in Arabidopsis. Plant Cell 21:607-621

Kalaji MH, Schansker G, Brestic M et al (2017) Frequently asked questions about chlorophyll fluorescence, the sequel. Photosynth Res 132:13-66

Keunen E, Peshev D, Vangronsveld J, Van Den Ende W, Cuypers A (2013) Plant sugars are crucial players in the oxidative challenge during abiotic stress: extending the traditional concept. Plant Cell Environ 36:1242-1255

Khan NA (2004) An evaluation of the effects of exogenous ethephon, an ethylene releasing compound, on photosynthesis of mustard (Brassica juncea) cultivars that differ in photosynthetic capacity. BMC Plant Biol 4:21. https://doi.org/10.1186/1471-2229-4-21

Klughammer C, Schreiber U (2008) Saturation pulse method for assessment of energy conversion in PS I. PAM Appl Notes $1: 11-14$

Kocsy G, Tari I, Vanková R, Zechmann B, Gulyás Z, Poór P, Galiba G (2013) Redox control of plant growth and development. Plant Sci 211:77-91

Krause GH, Weis E (1991) Chlorophyll fluorescence and photosynthesis. the basics. Ann Rev Plant Physiol Plant Mol Biol 42:313-349

Lei Y, Zheng Y, Dai K, Duan B, Cai Z (2014) Different responses of photosystem I and photosystem II in three tropical oilseed crops exposed to chilling stress and subsequent recovery. Trees 28:923-933

Miyake C, Miyata M, Shinzaki Y, Tomizawa K (2005) $\mathrm{CO}_{2}$ response of cyclic electron flow around PSI (CEF-PSI) in tobacco leavesrelative electron fluxes through PSI and PSII determine the magnitude of non-photochemical quenching (NPQ) of Chl fluorescence. Plant Cell Physiol 46:629-637 
Nascimento FX, Rossi MJ, Glick BR (2018) Ethylene and 1-aminocyclopropane-1-carboxylate (ACC) in plant-bacterial interactions. Front Plant Sci 9:114. https://doi.org/10.3389/fpls.2018.00114

Nishizawa A, Yabuta Y, Shigeoka S (2008) Galactinol and raffinose constitute a novel function to protect plants from oxidative damage. Plant Physiol 147:1251-1263

Pallas JE, Kays SJ (1982) Inhibition of photosynthesis by ethylene-a stomatal effect. Plant Physiol 70:598-601

Peshev D, Van den Ende W (2013) Sugars as antioxidants in plants. In: Tuteja N, Gill SS (eds) Crop improvement under adverse conditions. Springer, Berlin, pp 285-308

Pierik R, Tholen D, Poorter H, Visser EJW, Voesenek LACJ (2006) The Janus face of ethylene: growth inhibition and stimulation. Trends Plant Sci 11:176-183

Poór P, Gémes K, Szepesi Á, Horváth F, Simon LM, Tari I (2011) Salicylic acid treatment via the rooting medium interferes with the stomatal response, $\mathrm{CO}_{2}$ fixation rate and carbohydrate metabolism in tomato and decreases the harmful effects of subsequent salt stress. Plant Biol 13:105-114

Poór P, Borbély P, Kovács J, Papp A, Szepesi Á, Takács Z, Tari I (2014) Opposite extremes in ethylene/nitric oxide ratio induce cell death in cell suspension culture and in root apices of tomato exposed to salt stress. Acta Biol Hung 65:428-438

Poór P, Kovács J, Borbély P, Takács Z, Szepesi Á, Tari I (2015) Salt stress-induced production of reactive oxygen-and nitrogen species and cell death in the ethylene receptor mutant Never ripe and wild type tomato roots. Plant Physiol Biochem 97:313-322

Rodríguez-Serrano M, Romero-Puertas MC, Zabalza A, Corpas FJ, Gómez M, Del Río LA, Sandalio LM (2006) Cadmium effect on oxidative metabolism of pea (Pisum sativum L.) roots. Imaging of reactive oxygen species and nitric oxide accumulation in vivo. Plant Cell Environ 29:1532-1544

Santner A, Calderon-Villalobos LIA, Estelle M (2009) Plant hormones are versatile chemical regulators of plant growth. Nature Chem Biol 5:301-307

Saranga Y, Zamir D, Marani A, Rudich J (1993) Breeding tomatoes for salt tolerance: variations in ion concentrations associated with response to salinity. J Am Soc Hort Sci 118:405-408

Schachtman DP (2015) The role of ethylene in plant responses to $\mathrm{K}^{+}$deficiency. Front Plant Sci 6:1153. https://doi.org/10.3389/ fpls.2015.01153

Shabala S, Pottosin I (2014) Regulation of potassium transport in plants under hostile conditions: implications for abiotic and biotic stress tolerance. Physiol Plant 151:257-279

She X-P, Song XG (2012) Ethylene inhibits abscisic acid-induced stomatal closure in Vicia faba via reducing nitric oxide levels in guard cells. NZ J Bot 50:203-216. https://doi.org/10.1080/00288 25X.2012.661064

Shin K, Lee S, Song W-Y, Lee R-A, Lee I, Ha K, Koo J-C, Park S-K, Nam H-G, Lee Y, Soh M-S (2015) Genetic identification of ACC-RESISTANT2 reveals involvement of LYSINE HISTIDINE TRANSPORTER1 in the uptake of 1-aminocyclopropane1-carboxylic acid in Arabidopsis thaliana. Plant Cell Physiol 56:572-582

Staal M, De Cnodder T, Simon D, Vandenbussche F, Van der Straeten D, Verbelen J-P, Elzenga T, Vissenberg K (2011) Apoplastic alkalinization is instrumental for the inhibition of cell elongation in the Arabidopsis root by the ethylene precursor 1-aminocyclopropane-1-carboxylic acid. Plant Physiol 155:2049-2055

Steffens B, Sauter M (2009) Heterotrimeric G protein signalling is required for epidermal cell death in rice. Plant Physiol 151:732-740

Sun J, Li L, Liu M, Wang M, Ding M, Deng S, Lu C, Zhou X, Shen $X$, Zheng X, Chen S (2010) Hydrogen peroxide and nitric oxide mediate $\mathrm{K}^{+} / \mathrm{Na}^{+}$homeostasis and antioxidant defense in
$\mathrm{NaCl}$-stressed callus cells of two contrasting poplars. Plant Cell Tiss Org Cult 103:205-215

Szepesi Á, Csiszár J, Gémes K, Horváth E, Horváth F, Simon LM, Tari I (2009) Salicylic acid improves the acclimation to salt stress by stimulating abscisic aldehyde oxidase activity and abscisic acid accumulation, and increases $\mathrm{Na}^{+}$contents of the leaves without toxicity symptoms in Solanum lycopersicum L. J Plant Physiol 166:914-925

Takács Z, Poór P, Szepesi Á, Tari I (2017) In vivo inhibition of polyamine oxidase by a spermine analogue, MDL-72527, in tomato exposed to sublethal and lethal salt stress. Funct Plant Biol 44:480-492

Tari I, Kiss G, Deér AK, Csiszár J, Erdei L, Gallé Á, Gémes K, Horváth F, Poór P, Szepesi Á, Simon LM (2010) Salicylic acid increased aldose reductase activity and sorbitol accumulation in tomato plants under salt stress. Biol Plant 54:677-683

Taylor GE, Gunderson CA (1986) The response of foliar gas exchange to exogenously applied ethylene. Plant Physiol 82:653-657

Toon GC, Blavier J-FL, Sung K (2018) Measurements of atmospheric ethene by solar absorption FTIR spectrometry. Atmos Chem Phys 18:5075-5088. https://doi.org/10.5194/acp-18-5075-2018

Trujillo-Moya C, Gisbert C (2012) The influence of ethylene and ethylene modulators on shoot organogenesis in tomato. Plant Cell Tiss Org Cult 1:11-41

Tsang DL, Edmond C, Harrington JL, Nühse TS (2011) Cell wall integrity controls root elongation via a general 1-aminocyclopropane1-carboxylic acid-dependent pathway. Plant Physiol 156:596-604

Van de Poel B, Van Der Straeten D (2014) 1-Aminocyclopropane1-carboxylic acid (ACC) in plants: more than just the precursor of ethylene! Front Plant Sci 5:640. https://doi.org/10.3389/ fpls.2014.00640

Wang T-W, Arteca RN (1992) Effects of low $\mathrm{O}_{2}$ root stress on ethylene biosynthesis in tomato plants (Lycopersicon esculentum Mill cv Heinz 1350). Plant Physiol 98:97-100

Wang H, Liang X, Wan Q, Wang X, Bi Y (2009) Ethylene and nitric oxide are involved in maintaining ion homeostasis in Arabidopsis callus under salt stress. Planta 230:293-307

Wellburn AR, Lichtenthaler HK (1984) Formulae and program to determine total carotenoids and chlorophylls a and $\mathrm{b}$ of leaf extracts in different solvents. In: Sybesma C (ed) Advances in photosynthesis research. Advances in agricultural biotechnology. Martinus Nijhoff/Dr W Junk, The Hague, pp 10-12

Wi SJ, Jang SJ, Park KY (2010) Inhibition of biphasic ethylene production enhances tolerance to abiotic stress by reducing the accumulation of reactive oxygen species in Nicotiana tabacum. Mol Cells 30:37-49. https://doi.org/10.1007/s10059-010-0086-z

Woodrow L, Thompson RG, Grodzinski B (1988) Effects of ethylene on photosynthesis and partitioning in tomato, Lycopersicon esculentum Mill. J Exp Bot 39:667-684

Xu S-L, Rahman A, Baskin TL, Kieber JJ (2008) Two leucine-rich repeat receptor kinases mediate signalling, linking cell wall biosynthesis and ACC synthase in Arabidopsis. Plant Cell 20:3065-3079

Yang SF, Hoffman NE (1984) Ethylene biosynthesis and its regulation in higher plants. Ann Rev Plant Physiol 35:155-189

Yoon GM, Kieber JJ (2013) 1-Aminocyclopropane-1-carboxylic acid as a signalling molecule in plants. AoB Plants 5:plt017. https:// doi.org/10.1093/aobpla/plt017

Zaidi A, Khan MS, Ahmad E, Saif S, Rizvi A, Shadid M (2016) Growth stimulation and management of diseases of ornamental plants using phosphate solubilizing microorganisms: current perspective. Acta Physiol Plant 38:117. https://doi.org/10.1007/s1173 8-016-2133-7

Zhang F, Wang Y, Yang Y, Wu H, Wang D, Liu J (2007) Involvement of hydrogen peroxide and nitric oxide in salt resistance in the calluses from Populus euphratica. Plant Cell Environ 30:775-785 
Zhang G, Liu Y, Ni Y, Meng Z, Lu T, Li T (2014) Exogenous calcium alleviates low night temperature stress on the photosynthetic apparatus of tomato leaves. PLoS ONE 9(5):e97322. https://doi. org/10.1371/journal.pone.0097322
Zhang M, Smith JAC, Harberd NP, Jiang C (2016) The regulatory roles of ethylene and reactive oxygen species (ROS) in plant salt stress responses. Plant Mol Biol 91:651-699. https://doi.org/10.1007/ s11103-016-0488-1 